\title{
Paisagem Produtiva: a visão de mundo ambiental, racial e classista da elite canavieira nordestina (décadas de 1880 a 1930) \\ Thomas D. Rogers ${ }^{1^{*}}$
}

\section{RESUMO}

ROGERS, T. D. Paisagem produtiva: A visão de mundo ambiental, racial e classista da elite canavieira nordestina (décadas de 1880 a 1930). Este artigo descreve a perspectiva da elite Pernambucana sobre trabalho e meio ambiente na zona canavieira. Baseada numa análise de textos escritos por Joaquim Nabuco, Júlio Bello, José Lins do Rego, e Gilberto Freyre, o artigo sustenta que a elite percebia os engenhos como paisagens de trabalho, ou espaços de produção que incorporavam trabalhadores, solo e floresta juntos numa totalidade. Formada no contexto de escravidão, esta perspectiva persistiu depois da transição para trabalho livre. O artigo examina a presença durável desta perspectiva, utilizando o conceito de habitus descrito por Pierre Bourdieu. Acostumado aos privilégios de poder, a elite tinha o hábito de mandar, e tudo nos engenhos era suscetível ao seu mando. Os textos dos autores revelam todos os aspectos dessa maneira de ver e entender o mundo.

Palavras-chave: açúcar; senhores de engenho; trabalhadores rurais; raça; paisagem.

\begin{abstract}
ROGERS, T. D. Laboring Landscapes: The Environmental, Racial, and Classicist Worldview of the Brazilian Northeast's Sugar Elite, 1880s-1930s. This article describes the Pernambucan elite's perspective towards labor and environment in the state's sugarcane region. Based on an analysis of texts written by Joaquim Nabuco, Júlio Bello, José Lins do Rêgo, and Gilberto Freyre, the article argues that the elite saw sugar plantations as laboring landscapes, or production spaces that incorporated workers, fields, and forest together into a totality. Formed in the context of slavery, this perspective persisted until after the free labor transition. The article examines this perspective's durability, using Pierre Bourdieu's notion of habitus. Accustomed to the power privileges, the elite maintained the habit of command and everything on the plantations was susceptible to their control. These authors' texts reveal every aspect of this mode of seeing and understanding the world.
\end{abstract}

Key words: sugar; sugar masters; rural workers; landscape.

* Tradução de Alexandre Fortes. Texto original: ROGERS, Thomas D. Laboring landscapes. The environmental, racial, and class worldview of the Brazilian Northeast's sugar elite, 1880-1930s. Luso-Brazilian Review. 46:2, p. 22-53, 2009. 
A grandeza da terra era a sua grandeza. Fixara-se em mim a certeza de que o mundo inteiro estava ali dentro. Não podia haver nada que não fosse do meu avô. Lá ia o gado para o pastoreador, e era dele; lá saíam os carros-de-boi a gemer pela estrada ao peso das sacas de lã ou dos sacos de açúcar, e tudo era dele; lá estavam as negras da cozinha, os moleques da estrebaria, os trabalhadores do eito, e tudo era dele... (LINS DO REGO, 1957 [1956], p. 55- 56).

Assim José Lins do Rego descreve o seu avô plantador de cana, junto ao qual o escritor cresceu. Nessa passagem das suas memórias, Lins do Rego expressa os elementos centrais na visão de poder da elite canavieira no começo do século XX. Quando olhava para suas lavouras, a classe dos plantadores via uma paisagem produtiva - incluindo tanto elementos humanos quanto não humanos, era um espaço a ser comandado visando à produtividade material e simbólica. ${ }^{2}$

Outros filhos da aristocracia plantadora, incluindo o abolicionista pernambucano Joaquim Nabuco, refletiram nos seus escritos a relação entre terra, poder e produção. Padrões de longa duração de uso da terra, normas legais relativas à propriedade e, mais importante ainda, o peso de mais de três séculos de escravidão africana, estruturavam a visão dos plantadores. Uma análise dos escritos de Nabuco revela uma perspectiva muito semelhante àquela presente na passagem das memórias de Lins do Rego citada acima. Por sua vez, muitas das ideias centrais de Nabuco, assim como o seu apego sentimental à sua terra natal canavieira, são acolhidas nos escritos do influente intelectual Gilberto Freyre. Lins do Rego, também da geração de Freyre, evocou tanto em ficção quanto em não ficção uma visão da paisagem canavieira que combinava elementos insensíveis (solo, água) e residentes humanos (especificamente, trabalhadores negros) em uma totalidade produtiva. Finalmente, um plantador de cana-de-açúcar chamado Júlio Bello, que publicou uma autobiografia ao mesmo tempo em que Freyre e Lins do Rego publicavam suas obras influentes, articulou ideias que contribuem para o argumento de que a elite possuía uma visão sobre o meio ambiente que pode ser caracterizada como uma paisagem produtiva.

Esses quatro indivíduos - um político, um escritor, um cientista social e um plantador - representam um corte transversal significativo da pequena elite pernambucana. Como não havia uma literatura popular expressando uma visão de mundo distinta no período, as memórias, a ficção e os textos históricos e sociológicos desses homens cobrem uma ampla parcela da cultura escrita. Havia, por certo, outros fóruns para expressão da elite, incluindo os políticos mais proeminentes, e embora esse artigo utilize alguns dos escritos políticos de Nabuco (incluindo o seu texto seminal sobre o abolicionismo), ele não explora os debates políticos do final do século XIX e começo do século XX. Muitos dos textos sob análise aqui podem ser vistos como parte do mesmo gênero num sentido amplo, já que muito do seu conteúdo, e de forma ainda mais acentuada o seu tom, gira em torno da memória e da nostalgia. As memórias de Nabuco, Bello e Lins do Rego são elas mesmas debatidas, e muitos dos escritos sociológicos de Freyre enfocando a história de Pernambuco lidam com formas sociais que estavam se transformando no próprio momento em que ele escrevia. Além disso, a visão que guiava os escritos desses homens era profundamente marcada por uma concepção de papéis de gênero cujos postulados perpassam a própria trama dos textos; papéis esses que se relacionavam, por sua vez, às próprias heranças que conformam suas perspectivas em relação ao poder e à paisagem. ${ }^{3}$

Os textos analisados aqui não apenas difundem e refletem uma visão de mundo; eles reagem a uma paisagem e ajudam a criá-la, tanto nas mentes quanto no mundo material. Uma paisagem é a expressão tanto do impacto social sobre o meio ambiente quanto do saldo das influências do meio ambiente sobre a sociedade. A palavra "paisagem" implica o produto compartilhado da relação dialética entre humanos e o seu contexto próximo. Criticamente, o termo porta uma referência às ideias e perspectivas em relação ao meio ambiente prevalente num determinado lugar; paisagens 
emergem com a ligação duradoura entre ideias e lugares. ${ }^{4} \mathrm{~A}$ paisagem funciona aqui tanto como uma heurística para uma melhor compreensão da forma e da durabilidade de uma perspectiva de elite quanto como um objeto da criação daquela perspectiva. Os textos analisados ajudaram a estruturar o que a elite via no seu entorno e o que ela sentia em relação a ele. Partindo das bases estabelecidas pelo trabalho de síntese brilhante de Durval Muniz de Albuquerque Jr. (2004), que traçou uma nuançada pintura da forma como o Nordeste foi criado pelas elites, pelos intelectuais e por outros atores, este artigo adota uma visão do tema particularmente orientada pela espacialidade. Essa abordagem nos ajuda a compreender a persistência da visão da elite - articulada desse modo ao ambiente material - diante dos eventos políticos posteriores do século XX. ${ }^{5}$

As dinâmicas da visão paisagística da elite são explicadas com o auxílio do conceito de habitus de Pierre Bourdieu e de um aprofundamento do exame da noção de mando. Habitus refere-se à expressão viva de crenças e entendimentos que atravessam as gerações (BOURDIEU, 1977, p. 76 79). A percepção de paisagem da elite canavieira foi profundamente influenciada pela experiência com o direito de mando. Em escritos do começo do século XX, o mando se expressa numa ética, num guia de conduta na gestão das lavouras, e se estende além das relações interpessoais para incluir o domínio sobre a natureza. Essa concepção ajuda a conformar um habitus peculiar ao plantador, que por sua vez se perpetua na visão da elite sobre a paisagem produtiva. Com esse uso específico do conceito de habitus, o artigo revela a relação entre história intelectual e geografia para mostrar o que Cynthia Radding (2005, p. 5) denomina "as camadas de significado moral e histórico de paisagens e geografias particulares," um tipo de pensamento socioambiental que tem consequências para além de uma pequena coorte literária. ${ }^{6}$

\section{Terra e poder no Brasil}

Na sua magistral “memória" da Mata Atlântica brasileira, Warren Dean (1995, p. 6) argumenta que os brasileiros do período colonial nunca atribuíram valor inerente à terra, por vários bons motivos. ${ }^{7}$ Primeiro, toda a terra pertencia à Coroa. A Coroa distribuía o direito de uso por meio de concessões, que expiravam com a morte do titular. Isso garantia um dono "alienado" e não dava às famílias nenhum incentivo para fazer melhoramentos na propriedade. Segundo, tratar a propriedade com cuidado oferecia poucas recompensas mesmo durante o tempo de vida, pois mais terra podia ser requisitada quando a original ficasse "cansada." Finalmente, a concentração extrema de propriedade deixava todos os outros, posseiros ou agregados, sem um interesse investido na saúde de longo prazo da terra que eles ocupavam (DEAN, 1995, p.108, 151-152). Essas considerações originalmente produziram e nutriram a extrema concentração de propriedade e tiveram consequências de longo prazo. A terra tanto expressa quanto confere poder e o engrandecimento da propriedade requer poder.

Visões sobre a posse da terra estruturadas pelo sistema colonial persistiram muito tempo depois do Brasil conquistar sua independência de Portugal em 1822. Em 1850, o parlamento imperial promulgou a lei de terras, transformando assim a terra em mercadoria precisamente no momento em que a habilidade de comprar seres humanos do além-mar como mercadorias se tornava ilegal (COSTA, 2000, p. 79). Não foi por acaso que a lei de terras foi aprovada apenas quatorze dias após a lei que aboliu o tráfico de escravos. A consciência da elite sobre a urgência em responder à iminente abolição da escravidão desencadeou o debate sobre a lei de terras (CARVALHO, 1981, p. 47,51 ). Eles sabiam que uma parcela maior da sua riqueza derivava mais do capital representado pelos escravos do que do valor da terra (GALLOWAY, 1971, p. 596-597). Os legisladores seguiram conscientemente o exemplo da Austrália, onde burocratas advogaram preços artificialmente 
inflacionados para a terra que forçariam os imigrantes a trabalhar por certo período antes de ganhar o suficiente para ter a sua própria terra, como um meio de manter uma fonte de trabalho disponível numa situação de abundância de terras (CARVALHO, 1981, p. 40; COSTA, 2000, p. 82). ${ }^{8}$ Terra e trabalho continuariam a ser debatidos como um complexo entrelaçado no parlamento brasileiro mesmo após a passagem da lei de 1850 .

Contudo, a propriedade em si não guiava necessariamente as relações sociais da classe dominante. Os plantadores davam mais valor ao efeito do que ao fato da propriedade. Eles reconheciam a importância de controlar a terra e os recursos, não necessariamente de celebrar a cerimônia da propriedade administrada por agrimensores, notários e cartórios. Naquele mundo, o poder da propriedade poderia se fazer sentir sem a necessidade de um título inscrito no registro de imóveis. $\mathrm{O}$ resultado era uma elasticidade na compreensão da propriedade. Na sociedade brasileira, mesmo durante a escravidão, o "dever de obediência" ia muito além do escravo. (FRENCH, 2002, p.1415). Os plantadores o entendiam como o seu direito de mando sobre o trabalho, assim como sobre o solo, já que o último era de pouco valor sem o primeiro. Essa visão tanto contribuiu como resultou em um estreito vínculo entre trabalho e terra nas mentes dos plantadores e políticos do século XIX e teve consequências importantes para a continuidade da formação social após a abolição da escravidão (CARVALHO, 1981, p. 51).

A criação do mercado de terras, como aponta Donald Worster (1990, p.1099-1100), resultou no fato de que "todas as complexas forças e interações, seres e processos que denominamos 'natureza'... [foram] compactados em uma abstração simplificada, 'terra.'” No Nordeste brasileiro, todavia, a questão da terra reteve uma íntima relação com a questão do trabalho e a abstração que derivou do prolongado debate sobre ela envolveu mais do que a "natureza.". A abstração representada pela propriedade era importante, mas ao invés de ser simplificada na noção de "terra," a propriedade significava "mando." O trabalho permaneceu entrelaçado no mesmo tecido social que a terra como um recurso que poderia ser comandado juntamente com as árvores ou com o solo que era visivelmente vinculado à terra. Até 1888 a fonte primária de trabalho para os plantadores também assumia a forma legal de propriedade; a escravidão tornava direta a relação terra-trabalho e as prerrogativas da autoridade.

A terra (como território) desempenhava um papel pequeno nas disputas sobre "terra"; o que estava em jogo de fato era o conjunto de recursos associados à terra. Já que a agricultura de coivara predominava, os plantadores buscavam florestas que pudessem ser reduzidas às cinzas, nas quais eles plantariam suas lavouras (DEAN, 1995, p. 77). Enquanto houvesse mais disponível, os proprietários de terra do Nordeste brasileiro tendiam a não se apegar à dimensão precisa da terra que eles possuíam. Isso ajuda a contextualizar a cultura de um plantador em particular, que confessou sua ignorância sobre o tamanho exato das suas posses, para a surpresa de Tollenare, viajante francês do século XIX (1956, p. 70). Os primeiros colonos, requisitando concessão após concessão, estabeleceram o padrão na sua abordagem em relação à terra. $\mathrm{O}$ que eles buscavam, no caso do Nordeste, eram os elementos que lhes habilitassem a produzir açúcar. Não importava se fosse em lugar ou em outro. Daí a imprecisão com que os plantadores viam as suas posses, sem se importar em verificar os seus limites exatos e sem preocupar-se com o status legal da propriedade. Essa abordagem em relação à posse da terra produziu um paradoxo: "apesar da facilidade com que muitos pretendentes obtinham múltiplas [concessões] e do consequente baixo valor da terra, o axioma era que 'a terra é a maior riqueza,' porque apenas a ela atribuía-se prestígio." (DEAN, 1995, p.148). Dean deduz corretamente que prestígio era distinto de riqueza em si; na verdade poder e prestígio coincidiam apenas para aqueles que comandassem o trabalho necessário para fazer a terra produzir. 
Com essa configuração, o trabalho torna-se conceitualmente imerso, na visão dos plantadores, no terreno natural sobre o qual eles reinavam. Essa naturalização do status dos trabalhadores refletia-se na linguagem coisificante dos plantadores, por meio da referência aos escravos como "peças." Mas a continuidade da escravidão não era necessária para a manutenção do vínculo entre trabalhadores e terra. A perspectiva permanecia por inércia ao longo de gerações cuja experiência de vida se formava em um mundo no qual poder, riqueza, trabalho, raça, gênero e meio ambiente estavam atrelados uns aos outros. Aqueles que detinham o poder não apenas controlavam terra e trabalho, eles comandavam a paisagem produtiva.

Havia várias características persistentes do meio cultural de Pernambuco que contribuíram para o desenvolvimento dessa visão de mundo particular da elite. Primeiro, havia o profundo e pervasivo senso de crise, uma era dourada perdida e um grande futuro adiado ou roubado. ${ }^{10}$ As mudanças econômicas do século XIX no Brasil não favoreceram os plantadores nordestinos. As duas principais mercadorias de exportação do Nordeste geravam cerca de metade da renda do país em 1822, mas em 1913 computavam desprezíveis três por cento (LEFF, 1997, p. 35-36). Se a própria indústria do açúcar sofria de uma cultura de crise, a sociedade também era marcada por um senso de perda, um mal que era apenas agravado pelas perturbações econômicas e sociais da virada do século XX. A transição das plantações familiares (engenhos) para as grandes unidades industriais (usinas) trouxe mobilidade descendente para grande parte da elite canavieira tradicional. Como tem sido geralmente destacado, os proprietários de usinas frequentemente vinham das famílias de plantadores tradicionais, mas havia muito menos deles e a queda simbólica do plantador do seu posto no topo do poder patriarcal pode ter sido mais amargo que as realidades materiais da transição. Em segundo lugar, e relacionado com essa primeira característica, havia um sentimento em Pernambuco de que a terra tinha sido feita sob medida para o cultivo da cana-de-açúcar, que se adaptava perfeitamente às colinas suaves e úmidas do estado. A agricultura era vista como a atividade econômica mais nobre. A tendência do país rumo à industrialização e à urbanização aceleradas ia de encontro à ética institucionalizada da elite.

A estabilidade das atitudes dos plantadores encontra confirmação em um interessante debate no interior da indústria canavieira antes da abolição da escravidão. Em 1878, a Secretaria da Agricultura de Pernambuco, juntamente com grandes plantadores, sediou uma conferência regional de agricultura em Recife. A discussão centrou-se sobre questões de mão-de-obra, face ao debate em curso sobre a abolição da escravidão, e sobre desenvolvimento, particularmente em termos de crédito e financiamento. A opinião de alguns participantes, de que o setor açucareiro se caracterizava por um atrasado "amor pela rotina" foi rebatida por outro participante eloquente, que defendia que os plantadores mantinham um conjunto de práticas saudáveis fundamentadas na sua longa experiência (SOCIEDADE AUXILIADORA..., 1978, p. 114). ${ }^{11} \mathrm{O}$ interessante nesse debate é que todos os participantes concordavam que os plantadores seguiam um conjunto de práticas que tinham sido passados de geração em geração. Esse senso de continuidade e estabilidade não se restringia ao reino da tecnologia agrícola, mas perpassava todo o sistema de plantio, incluindo a relação com os trabalhadores. Na verdade, os plantadores provavelmente não viam diferenças claras entre relações de trabalho e práticas agrícolas. ${ }^{12}$ Mais lições sobre os vínculos entre terra e trabalho aparecem na obra do famoso abolicionista pernambucano Joaquim Nabuco.

\section{O fim da "tribo patriarcal": Joaquim Nabuco sobre abolicionismo, terra e trabalho}

Em março de 1879, Joaquim Nabuco subiu à tribuna do parlamento imperial para falar sobre o que ele chamava de "o problema da época" - a transição do trabalho escravo para o trabalho livre. Ele 
argumentava que a transição no trabalho poderia ocorrer apenas quando os trabalhadores obtivessem certo grau de independência. Isso, por sua vez, seria possível apenas com o estabelecimento de um imposto territorial, que ajudaria na divisão das posses massivas da elite. Referindo-se à falta de um cadastro geral de terras, ele afirmava que "o Brasil é ainda mais desconhecido do que a África equatorial. O Brasil é que tem maior porção de terras desconhecidas, onde nunca penetrou um geógrafo e é por isso que sinto que a comissão da carta do Brasil fosse extinta, porque não há país que mais precise de estudos geográficos do que nós." (NABUCO, J., 1949, p. 18-19) ${ }^{13}$ Perto do final do século XIX, os grandes proprietários ainda reinavam sobre domínios cujos limites eram definidos tanto pelo alcance do seu poder quanto por levantamentos geográficos.

Os colegas de parlamento de Nabuco na época, assim como seus amigos e patronos por todo o país, sabiam que o Império não levaria a cabo tão cedo um levantamento cadastral para começar a taxar adequadamente as grandes propriedades; as famílias terratenentes eram poderosas demais para permitir isso. A lei de 1850 tinha decretado a criação de um imposto territorial, junto com o requerimento do levantamento e do registro de terras (DEAN, 1971, p. 619-621). Mas apesar do interesse pela modernização das provisões do código civil com relação à terra, o Império ainda estava atrelado a alguns legados coloniais, incluindo uma marcada deferência à elite agrária. Assim, se a lei estabeleceu um mercado de terras, ela também serviu mais para proteger do que para ameaçar aqueles que já possuíam terra (COSTA, 2000, p. 85, 91-92; DEAN, 1995, p. 201). Supostamente, deveria haver relatórios sobre terras que não estavam em uso ativo, produtivo, e elas deveriam ser colocadas sob controle do Império para futura venda. Contudo, apesar dos latifúndios imensamente extensos com grandes áreas inutilizadas, pouquíssimas terras foram revertidas para o Império e a maioria das reivindicações informais (sem título) feitas pelos proprietários foram legitimadas. O grau de controle dos grandes proprietários em Pernambuco era tal que foi relatada apenas meia légua de terra inutilizada (DEAN, 1971, p. 622).

Nabuco seguiu em frente e tornou-se o líder mais visível do movimento abolicionista no Brasil. Ele organizou um partido político abolicionista nacional e publicou $O$ abolicionismo, seu famoso tratado sobre o tema, em 1883. Na visão do seu admirador Gilberto Freyre (1977, p. 15), esses esforços fizeram de Nabuco "um desertor de sua casta, de sua classe, de sua raça, cujos privilégios combateu com um vigor e um desassombro que, segundo o depoimento de Graça Aranha, deixou atônito o Parlamento da época." No seu trabalho, Nabuco mostrou que a escravidão estava intimamente vinculada ao sistema social sobre o qual a instituição se baseava. Para ele, a servidão legal definia o caráter da sociedade brasileira. Ele frequentemente incluía a natureza ou a terra quando citava os danos causados pela escravidão. Ele deixava claro que a instituição feria os seres humanos e o meio ambiente que os cercava. O Abolicionismo traz fortes afirmações sobre a relação entre escravidão e meio ambiente. Todo o desenvolvimento do Brasil, da "conquista do solo" à construção de ferrovias e telégrafos - em resumo, toda a acumulação de riquezas - escreveu Nabuco, "não passa de uma doação gratuita da raça que trabalha à que faz trabalhar” (NABUCO, J., 1977a, p. 20, 27). Ele apontava que a fonte desse subsídio forçado, a instituição da escravidão, mantinha o país num estado de atraso. Todos, que condenava os brasileiros "a formarem, como formam, uma nação de proletários." (NABUCOa, J.,1977, 84).

A ligação que Nabuco estabelecia entre a brutalidade humana da escravidão e o tratamento brutal do meio ambiente sob o sistema escravista ia além do dogma da época, de que a escravidão era simplesmente uma herança do passado. Como mostrou José Augusto Pádua (1998, p. 160), Nabuco compartilhava essa inovação intelectual com outros da última geração de abolicionistas, que chamaram a atenção para a destruição ambiental provocada pelo sistema de trabalho cativo. O progresso, eles acreditavam, significava o fim da anacrônica escravidão e o triunfo sobre a 
degradação ambiental..$^{14}$ Nabuco defendia que sob a escravidão não havia "consórcio do homem com a terra;" assim, onde quer que tenha havido escravidão, o "solo voltou à Natureza, estragado e exausto." Nabuco $(1977$ a, p.105, 117) oferecia uma narrativa sombria especificamente sobre Pernambuco: "A cada passo encontramos e sentimos os vestígios deste sistema que reduz um belo país tropical ao aspecto das regiões onde se esgotou a força criadora da terra... Onde quer que se a estude, a escravidão passou sobre o território e os povos que a acolheram como um sopro de destruição." Como uma perversão do cultivo livre e generalizado do solo, Nabuco caracterizava a escravidão como "uma luta do homem contra a terra." (NABUCO, J., 1977a, p. 111, grifo nosso). Próximo ao fim da vida, Nabuco descreveria os campos ondulados de cana de Pernambuco em termos bastante diferentes, que refletiam uma visão emotiva de apego à paisagem regional. $\mathrm{Na}$ sua autobiografia de 1900 - um texto muito diferente do tratado abolicionista - Nabuco declarava nunca ter superado as impressões da sua primeira infância. "Os primeiros oito anos da vida," ele escreveu sobre o tempo que passou na zona canavieira, "foram assim, em certo sentido, os de minha formação, instintiva ou moral, definitiva." Usando abundantes detalhes para descrever sua infância na lavoura, ele se recorda que "na planície estendiam-se os canaviais cortados pela alameda tortuosa de antigos ingás carregados de musgos e cipós, que sombreavam de lado a lado o pequeno rio Ipojuca." (NABUCO, J., 1981 [1900], p. 129). Nabuco deixou a região açucareira com oito anos de idade e nunca voltou para casa; portanto, essas memórias vinculavam-se a uma infância distante, um fato que pode ter contribuído para a profundidade da nostalgia que elas expressam. ${ }^{15}$

O desagrado com a escravidão desapareceu nessas passagens, à medida que Nabuco mergulha em grande nostalgia pelo sistema social no qual ele nasceu. Ele admite (1981 [1900], p. 132) que a escravidão preservara-se na sua memória "como uma servidão gentil." "Receio que essa espécie particular de escravidão tenha existido somente em propriedades muito antigas," continuava, "administradas durante gerações seguidas com o mesmo espírito de humanidade, e onde uma longa hereditariedade de relações fixas entre o senhor e os escravos tivessem feito de um e outros uma espécie de tribo patriarcal isolada do mundo." ${ }^{16}$ Nabuco estabelece aqui uma distinção importante entre bons e maus senhores, ao invés de um posicionamento monolítico contra o sistema, uma visão que contrasta com a suas afirmações inequívocas em $O$ abolicionismo (1977b) de que a escravidão era a mesma em toda parte e má em essência. A cálida "aproximação entre situações tão desiguais perante a lei," Nabuco lamentou (1981 [1900], p. 132) que "seria impossível nas novas e ricas fazendas do Sul."

Nabuco reconhecia a centralidade do poder e do status masculino para o conjunto da estrutura social que girava em torno dos engenhos. Mas essa idílica família ampliada era uma relíquia manufaturada, uma regressão a um tempo mítico. A imagem de Nabuco, porém, refletia alguns aspectos da realidade do exercício do poder. Podemos imaginar Nabuco debruçando-se sobre suas memórias, memórias não da escravidão em si, mas de um senso de bem-estar associado com o conforto da superioridade e da dominação inconteste. ${ }^{17}$ Ele assemelha o comportamento dos escravos à "dedicação do animal que nunca se altera." Sugere também que as fazendas canavieiras do Nordeste não estavam relacionadas à geração de riqueza, mas antes à "conservação do estado do senhor, cuja importância e posição eram avaliadas pelo número de seus escravos.” (NABUCO, J., 1981, p. 132). Essa noção reforça a importância do status, assim como do papel do mando em assegurá-lo e perpetuá-lo. Pressupostos profundamente enraizados sobre posições de gênero formatavam a visão de Nabuco, à medida que ele descrevia o mundo dos engenhos girando sobre um centro masculino, com o privilégio do poder investido naquele patriarca (BEATTIE, 1977, 2005; CAULFIELD, 2000). 
A autobiografia de Nabuco ecoa um tom moral diferente de $O$ abolicionismo, mas ambos os textos ligam escravidão a lugar e ao meio ambiente. ${ }^{18}$ De fato, a afeição de Nabuco por esse modelo de relações sociais liga-se poderosamente à paisagem canavieira, algo que ele descreve de forma estranha e reveladora. "A escravidão permanecerá por muito tempo como a característica nacional do Brasil," ele escreveu, "espalhou por nossas vastas solidões uma grande suavidade..." E continua, "seu contato foi a primeira forma que recebeu a natureza virgem do país, foi a que ele guardou; ela povoou-o como se fosse uma religião natural e viva, com os seus mitos, suas legendas, seus encantamentos." Nabuco evoca assim o que era para ele uma aura indescritível, mas longe de maligna, cercando a instituição da escravidão. No curso dessa passagem particular, o uso da palavra escravidão por Nabuco transforma-se sutilmente. A princípio, ela significava um aspecto da sociedade como um todo, uma "característica nacional." Mas a seguir ela se torna uma força ativa, dando "forma à natureza virgem do país.” (NABUCO, J., 1981 [1900], p. 131) ${ }^{19}$

Os escritos de Nabuco oscilam do abolicionismo a plenos pulmóes ao memorialista indulgente em reverência nostálgica. De um lado, ele condena o sistema de trabalho que "deixa após de si um país devastado em que consegue vegetar uma população miserável de proletários nômades." (NABUCO, J.,1977a, p. 104). De outro lado, ele expressa o saudosismo pelo cálido toque de "o suspiro indefinível" que a escravidão legou ao passado da região. (NABUCO, J.,1981, p. 131). Mas o que é consistente nos escritos de Nabuco é a ideia de que o trabalho escravo de fato deu forma e deixou suas digitais numa natureza informe. Especificamente, ele moldou o Nordeste que conhecia e amava, produzindo uma paisagem singular. Além do mais, Nabuco fazia pouca diferenciação entre os elementos daquela paisagem. Sua descrição daquela paisagem fundia-se à sua descrição dos escravos, implicando uma tendência a não reconhecer distinções entre os trabalhadores africanos e a sua condição de cativeiro. Trabalhadores negros eram colocados no mesmo nível de diligentes burros e bois. De fato, eles estão também no mesmo nível da própria terra, que tinha sido "violada" pela instituição da escravidão. Ele pode eventualmente deplorar a escravidão e lamentar as perdas que ela gerou (e ao fazer isso ele não era mais contraditório que muitos dos liberais brasileiros do século XIX), mas reconhecia que ela era um componente integral e formativo da paisagem canavieira. A paisagem do Nordeste, para Nabuco, era um terreno trágico de trabalho africano uma paisagem produtiva.

\section{Um Brasil “adoçado pelo açúcar e pelo negro": o Nordeste de Gilberto Freyre}

No período que se estende da metade do século XIX até a década de 1930, o Brasil superou a escravidão e livrou-se da monarquia para tornar-se uma república. A indústria do café flexionou seus músculos no Rio de Janeiro, em Minas Gerais e, acima de tudo, em São Paulo, dirigindo conscientemente a economia da nação e espalhando o desenvolvimento pelo centro-sul. Gilberto Freyre respondeu a todas essas mudanças na sua formidável obra, que moldou a forma como várias gerações têm visto o Nordeste e o Brasil como um todo (MOTA, 1994, p. 54).

Com a publicação de Casa-Grande e Senzala em 1933, Freyre reorientou as discussões anteriores sobre os significados da nação, a importância da raça e a natureza da herança colonial brasileira. O livro, como comentou um importante crítico, representou uma "ruptura com a abordagem cronológica clássica" e "teve o peso de uma denúncia do atraso intelectual, teórico, metodológico, que caracterizava os estudos sociais e históricos no Brasil." (MOTA, 1994, p. 29-30). Thomas Skidmore (1993, p.191) declarou que ele "virou de cabeça para baixo o questionamento até então 
existente sobre os supostos danos irreversíveis causados pela miscigenação ao longo das gerações," uma das preocupações centrais da elite. Essas contribuições lhe trouxeram fama, mas em acréscimo a essas discussões, Freyre introduziu com força na agenda intelectual a questão das interações socioambientais.

Nos seus primeiros dois livros, Freyre abordou os dois lados do discurso de Nabuco sobre a escravidão e o passado da zona canavieira. Casa-Grande e Senzala mostra Freyre exultante, descrevendo a criação da rica e híbrida cultura brasileira, enquanto em Sobrados e Mucambos ele recorda a decadência dessa sociedade e seu tom muda para se tornar marcado por perda e amargor. Assim a cronologia implícita nos escritos de Nabuco - o tempo antigo da "tribo patriarcal" dando lugar ao capitalismo desalmado que revelava o núcleo podre da escravidão - foi explicitada por Freyre. Um olhar mais próximo sobre a obra de Freyre revela um débito significativo ao antigo estadista pernambucano. Uma convicção partilhada pelos dois homens envolvia a superioridade das relações patriarcais anteriores nos engenhos. Com o crescimento das fábricas, a obsolescência do velho sistema de plantation, o desabrochar da classe política, e o crescente empreendedorismo entre os imigrantes recentes, Emilia Viotti da Costa observa que Freyre e seus pares "confrontaramse com um novo estilo de vida e de política que eles não tinham muita certeza se lhes agradava." (COSTA, 2000, p. 244) ${ }^{20}$ Freyre glorificou os canaviais nordestinos em resposta a essa ansiedade, mas ele mesmo passou a vida na cidade. Foi já idoso que ele se retirou para um repouso suntuoso em Apipucos, um subúrbio de Recife que tinha sido um engenho muito tempo antes. Antes disso, sua experiência na zona canavieira tinha se limitado a visitas familiares. Seu próprio pai era um negociante de Recife e ele estava separado ao menos por uma geração de qualquer história familiar na produção de açúcar. ${ }^{21}$

A despeito da sua distância pessoal das plantações de cana, Freyre estabeleceu uma relação pessoal com elas e centrou o seu trabalho sobre elas. Lins do Rego tomou interesse pelo entusiasmo de Freyre quando os dois, ainda jovens, viajaram juntos à Paraíba. Ele levou Freyre às plantações familiares na porção paraibana da zona canavieira, "mostrando a minha gente e a minha terra". "Os partidos de cana, os banguês, os tios, as tias, e tudo aquilo," escreveu o romancista, "lhe parecendo melhor do que eu pensava que fosse. Levei-o com medo de que não se desapontasse, e, pelo contrário, gostou muito de tudo." (LINS DO REGO, 1941, p. 15). Ao considerá-la a "mais aristocrática" das regiōes do país, Freyre tratou o Nordeste como uma metonímia do país e como o verdadeiro berço da cultura e da civilização brasileiras. No seu trabalho, a história, a herança, e os legados da zona canavieira se misturavam à cultura da nação sem mediação. Ele argumentava que as partes constitutivas da sociedade canavieira nordestina tinham sido, e em algumas formas importantes continuavam a ser, "os elementos mais típicos da paisagem brasileira, física bem como social." (FREYRE, 1963b) ${ }^{22}$ O padrão básico de organização social brasileiro, Freyre deixava implícito, espelhava a zona canavieira. (MOTA, 1994, p. 56-58).

Freyre alcançou proeminência durante um período que veio a definir o Nordeste como uma região atrasada. ${ }^{23}$ Ele orgulhosamente louvou algumas das características que viriam a formar os elementos centrais dessa imagem como aqueles que tornaram a região tão importante para a história da nação - a persistência, por exemplo, de tradições pseudo-aristocráticas. Contradizendo a sua defesa de que o Nordeste é o centro da nação, Freyre (1989 [1937], p. 41-42) reconhecia que "há mais de dois Nordestes e não um, muito menos o Norte maciço e único que se fala tanto no Sul com exagero de simplificação." Ele aceitava (1989 [1937], p .17) a separação entre "o agrário e o pastoral," a costa úmida e o sertão seco (FREYRE, 1989[1937], p. 41-42). O seu Nordeste era a zona canavieira, "os Brasis mais adoçados pelo açúcar e pelo negro” como ele dizia sobre as passagens em que Nabuco falava do seu lar. ${ }^{24}$ Ainda assim, ele apresentava o Nordeste como a região mais típica do país ao 
mesmo tempo em que se desenvolvia a imagem de uma região fora do compasso na marcha do país rumo à modernidade. Era uma ode desafiante à tradição e uma tentativa de redirecionar o olhar da nação em direção à zona canavieira e ao seu passado.

Freyre também se recusava a adotar as ideias dominantes sobre as características físicas da sua região tropical. Quando Freyre nasceu, escreve Thomas Skidmore (2002, p. 3), "os brasileiros viviam à sombra de dois determinismos: raça e clima.” Embora separáveis em teoria, os dois estavam intimamente ligados na cabeça das pessoas. ${ }^{25}$ Freyre (1963b, p. 60) se referia a esses determinismos repetidamente e era explícito na sua intenção de desafiar o trabalho "dos que, esquecendo os regimes alimentares, tudo atribuem aos fatores raça e clima." ${ }^{26}$ Ele enfatizava a importância da dieta tanto na história de Portugal quanto na do Brasil, argumentando que a "inferioridade física do brasileiro" frequentemente atribuída à raça ou ao clima, de fato "deriva-se do mau aproveitamento dos nossos recursos naturais de nutrição.” (FREYRE, 1963b, p.45). Os réus a serem acusados por um império extenuado e por um colonialismo defeituoso eram a monocultura e o monopólio da terra. Freyre pensava que uma comparação com sociedades escravocratas em outras áreas geográficas, tais como as Antilhas e os Estados Unidos, revelava o primado de fatores sociais e econômicos sobre as influências da raça e do clima em relação ao desenvolvimento social. (FREYRE, 1963b, p. 48, 240, 401).

A despeito de sua convicção sobre esses pontos, Freyre sentia que o clima e o meio ambiente continuavam a ter um papel central no desenvolvimento do colonialismo brasileiro e por extensão, na sociedade brasileira contemporânea. Antes de Freyre, uma das vozes brasileiras mais fortes em relação ao assunto era Euclides da Cunha, que declarou no seu livro Os Sertões, de 1902 que "o homem do sertão tem uma relação funcional com a terra.” Da Cunha $(1944$, p.112) encontrou no sertão a "raça alicerce da nossa nação," uma raça forjada no calor e na poeira do interior pedregoso, uma mistura robusta de diferentes linhagens que representava algo novo e unicamente brasileiro. Da perspectiva de Freyre, a influência formativa do meio ambiente representava uma força democratizante - as diferentes raças do Brasil, mesmo tendo se misturado promiscuamente na cama, também convergiam devido ao meio ambiente que compartilhavam. ${ }^{27}$ Freyre também elaborou sua posição em relação aos acadêmicos que fizeram a maior parte dos pronunciamentos contemporâneos sobre o tema, negociando um cuidadoso caminho entre Ellen Churchill Semple, Ellsworth Huntington, Carl Ortwin Sauer, Griffith Taylor, Franz Boas, entre outros. ${ }^{28}$ Ele rejeitou Huntington, cujo Civilization and Climate (HUNTINGTON, 1915) teve grande influência entre as décadas de 1910 e de 1940, como um "fanático" na questão da influência climática. ${ }^{29}$

Freyre também não concordava totalmente com Semple, o geógrafo pioneiro da Universidade da Califórnia cujo livro de 1911, Influences of Geographic Environment, desafiou os vínculos deterministas entre meio ambiente e raça (SEMPLE, 1911). Numa passagem em que citava um trecho de Semple, Freyre concordava que "embora o clima já ninguém o considere o senhordeus-todo-poderoso de antigamente", ao mesmo tempo assinalava que continuava a acreditar na influência transformativa do meio ambiente. Ele escreveu: "é impossível negar-se a influência que exerce na formação e no desenvolvimento das sociedades, senão direta, pelos efeitos imediatos sobre o homem, indireta pela sua relação com a produtividade da terra, com as fontes de nutrição e com os recursos de exploração econômica acessíveis ao povoador." A partir dessa cuidadosa posição, Freyre fazia incursões ocasionais, arriscando proposições mais ambiciosas sobre os impactos dos "trópicos", sobre os portugueses e os co-fundadores, como ele os situava, da sociedade brasileira - o africano e o índio. Ele romantizava, por exemplo, a conexão entre os índios e a terra e lamentava que o invasor europeu tivesse desfeito "o equilíbrio nas relações do homem com o meio físico." 
"O açúcar matou o índio," Freyre concluía, e ele entendia que a monocultura de cana continuava a ter consequências lamentáveis para o meio ambiente nordestino. (FREYRE, 1963b, 18-19; 81; 179).

Os portugueses, em contraste com os índios, não tinham tradição (ao menos por várias centenas de anos) de proximidade com a paisagem, algo que Freyre (1963b, p. 32) atribuía ao "mercantilismo burguês e semita, por um lado, e, por outro, à escravidão moura sucedida pela negra." Ele detalhava a disjunção entre os colonizadores e o seu entorno, uma distância que ele argumentava ainda existir: "o fato de sermos ainda, em grande parte, um povo de integração incompleta no habitat tropical ou Americano." (FREYRE, 1963b, p.140) Ele chamava a atenção para a tendência dos seus compatriotas brasileiros de se referirem a qualquer criatura como, simplesmente, um bicho. "Mesmo na roça," ele concluía, "todo besouro é um cascudo e nada mais." (FREYRE, 1963b, p. $141)$.

Freyre escrevia num estilo guiado por imagens e metáforas ambientais, e ele frequentemente misturava características culturais e geográficas. Destilando efusivamente sobre a fertilidade ou a sensualidade das mulatas, ou "mulheres cor de massapé e de terra roxa," Freyre (1963b, p. 381) comparava suas virtudes às "melhores terras agrícolas da colônia." Em outro trecho ele escreve que o português "não se limitou a recolher da África a lama de gente preta que lhe fecundou os canaviais e os cafezais; que lhe amaciou a terra seca; que lhe completou a riqueza das manchas de massapé." (FREYRE, 1963b, p. 311). Essa passagem traz a marca da influência de Nabuco, que argumentou (1981, p. 131) que o contato com escravos africanos deu "a primeira forma que recebeu a natureza virgem do país, foi a que ele guardou." Mesmo em Nordeste, o "estudo ecológico" que Freyre escreveu sobre a região, ele se mostra encantado com aspectos da "civilização do açúcar." Ele amava a aristocracia, as damas banhando-se nos rios, a lista infinita de sobremesas adocicadas preparadas nas nobres casas grandes dos canaviais. (FREYRE, 1989 [1937], p. 57, 46, 148) ${ }^{30}$

Freyre sentia que a civilização do açúcar tomara a única forma que traria sucesso à empresa colonial, mas seu desenvolvimento teve consequências de peso para as noções de raça e trabalho. Em CasaGrande e Senzala, ele exortou os leitores a terem a honestidade de admitir que "só a colonização latifundiária e escravocrata teria sido capaz de resistir aos obstáculos enormes que se levantaram à civilização do Brasil pelo europeu”. Apenas "a casa-grande e a senzala", ele continua, "o senhor de engenho rico e o negro capaz de esfôrço agrícola e a êle obrigado pelo regime de trabalho escravo" poderiam realizar a "civilização" do Brasil. Esse processo civilizador transformou a paisagem tanto quanto os agentes da transformação. A combinação entre "a natureza e o sistema de trabalho" resultou no "abrasileiramento" dos escravos africanos. Essas forças também racializaram a própria natureza do trabalho. Freyre referiu-se diversas vezes ao desenvolvimento linguístico que produziu o verbo "mourejar" (derivado de "mouro") como sinônimo para trabalhar, e ele destaca o uso comum da frase "trabalhar como um mouro". (FREYRE, 1963b, p. 251; 376; 212). ${ }^{31}$ Pode-se compreender, ele escreveu, porque aqueles que fundaram a "lavoura de cana no trópico americano se tivessem impregnado, em condições de meio físico tão adversas ao seu esforço, do preconceito de que 'trabalho é só pra negro." O corolário do trabalho ser "para negro", apontava Freyre, era "o horror à atividade manual” entre os proprietários de escravos. (FREYRE, 1963b, p. 247; 235). ${ }^{32}$

Em Nordeste, de 1937, Freyre aborda explicitamente o meio ambiente da região e, de forma mais sutil, o trabalho por meio do qual ela foi transformada. É, em vários aspectos, um ensaio de fôlego, apresentado com força e paixão. Mas é tão contraditório quanto fervoroso. Mesmo que Freyre lamente os efeitos da monocultura canavieira em geral, certas passagens indicam o desejo de culpabilizar apenas as mudanças mais recentes na agricultura pelos crimes mais graves cometidos 
pelas lavouras. Ele acreditava que as novas usinas tinham cometido os atentados mais brutais contra "a natureza por [açúcar] degradada aos últimos extremos," e agravado "a deformação tão grande do homem e da paisagem pela monocultura." (FREYRE, 1989[1937], p. 162). Mais uma vez, a conceituação de Freyre sobre as consequências da agricultura canavieira assume as formas definidas por Nabuco. Essa citação em particular remete à afirmação de Nabuco de que o açúcar e a escravidão foram "um flagelo que imprimiu na face da sociedade e da terra todos os sinais da decadência prematura." (NABUCO, 1977a, p. 113). ${ }^{33}$

Freyre afirmou que Nordeste retratava "o drama de monocultura," e ele pode ser lido como uma extensa metáfora da história social e cultura da região. De fato, ele deixou clara essa posição de que a história natural da região era ao mesmo tempo a sua história social. É como se Freyre tivesse reescrito Casa-Grande e Senzala com o meio ambiente desempenhando o papel central ao invés dos portugueses, africanos e índios nos quais Freyre se concentrou no seu primeiro grande livro. Os elementos centrais permanecem - violência, sexo, acomodação e o forjar-se de uma nova cultura (nesse caso, uma monocultura). "Nunca foi mais violento nos seus começos," (FREYRE, 1989[1937], p. 74) ele escreveu, "o drama da monocultura do que no Nordeste do Brasil." (1989, p. 65). Os rios do Nordeste, ele escreveu, foram "prostituídos pelo açúcar," enquanto o canavial "desvirginou todo esse mato grosso do modo mais cru" da zona açucareira. Ele equiparava (FREYRE, 1989[1937], p. 73) essa "vegetação virgem” à "vida nativa” da região (isto é, os povos indígenas), expandindo a sua fusão sexualizada e racializada de terra e gente. Além de demonstrar a conexão entre os mundos natural e social, essas passagens ilustram claramente as concepções de gênero que marcam a visão de Freyre. Aqueles que exercem poder sobre o meio ambiente são invariavelmente figuras masculinas, mesmo que isso signifique uma cana-de-açúcar masculinizada. Ao mesmo tempo em que Freyre escrevia Nordeste, seu amigo e colega estava escrevendo dramas familiares situados na mesma paisagem.

\section{Um reino em miniatura: a paisagem canavieira na literatura da década de 1930}

Lins do Rego, um romancista da geração de Freyre, ganhou substancial fama em vida e também posteriormente, por seus livros autobiográficos nostálgicos, evocativos, escassamente ficcionalizados sobre a região canavieira. Lins do Rego tinha consciência de que o mundo da plantation não tinha grande apreço pelas letras. Ele escreveu que os filhos de plantadores entre seus colegas de turma em Olinda e Recife eram "rudes como os pais" e "indiferentes a toda e qualquer distração como os livros." Todavia, ele destacava Júlio Bello, que publicou uma detalhada e valiosa autobiografia chamada Memórias de um senhor de engenho, como uma exceção que provava a regra. (LINS DO REGO, 1985 [1935]). Essa seção examina os escritos desses dois filhos da cana, demonstrando as continuidades com Freyre de um certo discurso sobre terra e trabalho mas que também revela mudanças sutis nos termos do discurso. ${ }^{34}$

Nascido um ano antes de Freyre em 1901, Lins do Rego cresceu no seio de uma família produtora de açúcar na Paraíba - "esse sul da Paraíba de José Lins do Rego que é quase Pernambuco...," como escreveu Freyre - antes de se mudar para Recife. ${ }^{35}$ Localizado no rio Paraíba, o engenho que pertencia ao avô do jovem José fazia divisa com Pernambuco. A importância de Lins do Rego para a elaboração, desenvolvimento e persistência de um discurso de elite sobre a zona canavieira é inquestionável. Seus romances destilam a maior parte dos elementos daquele discurso na forma como apresentam o meio ambiente, o trabalho e as mudanças trazidas pela última década do século XIX e pelo início do século XX. Iniciando com a publicação de Menino de Engenho em 1932, Lins do Rego produziu uma série de romances, ensaios e memórias que obtiveram incrível penetração 
no mundo mental da região, um feito realizado em parte por meio da incorporação generalizada dos livros em currículos escolares. Lins do Rego reconheceu ter sido influenciado fortemente por Freyre, mas ele foi além das ideias do seu parceiro em vários aspectos significativos. ${ }^{36}$

Menino de Engenho foi o primeiro de uma sequência de cinco romances que se tornaram conhecidos como "Ciclo da cana-de-açúcar", o último dos quais foi publicado em 1936. Fogo Morto, o romance de Lins do Rego mais aclamado pela crítica, apareceu em 1943, e depois disso ele escreveu principalmente curtas peças ficcionais e autobiográficas, até morrer em 1957. ${ }^{37}$ Sobre o "Ciclo da cana-de-açúcar”, Lins do Rego registrou (1940, p. 7) que queria "apenas escrever umas memórias que fossem as de todos os meninos criados nas casas grandes dos engenhos nordestinos." Mas os livros ganharam vida própria, ele justificava, e trouxeram à tona coisas que estavam "escondidas no seu interior." De fato, após ler suas memórias, fica imediatamente claro que ao menos Menino de Engenho é patente e transparentemente autobiográfico. Essas memórias focam exclusivamente no que Lins do Rego denominou "meus verdes anos" - os primeiros anos de infância. Ele busca reconquistar o controle sobre essas experiências precoces que, como escreveu, "se foram no tempo, mas que ainda se fixam no escritor que tanto se alimentou de suas substâncias." (LINS DO REGO, 1957 [1956], p. 6) ${ }^{38}$ Esse material mostrou-se atraente para um grande número de leitores, especialmente considerando-se que sua trama era tecida por um discurso que já era familiar ao menos aos leitores nordestinos.

Enquanto Lins do Rego passou a infância do outro lado do rio Paraíba, Bello cresceu às margens do rio Persinunga, que marca a divisa do sul de Pernambuco com Alagoas. ${ }^{39}$ Bello nasceu em 1873 - entre as datas de nascimento de Nabuco e de Freyre - no Engenho Tentugal, municípo de Barreiros, na parte sul da zona canavieira. ${ }^{40}$ Após frequentar a escolar, ele regressou à "casa patriarcal" e herdou o manto de seu pai como senhor do Engenho Queimadas (BELLO, 1985, p. 85). As memórias de Bello apareceram originalmente em 1935, com prefácios escritos por Freyre e Lins do Rego.

Assim como Freyre, Lins do Rego e Bello reconheceram as mudanças econômicas e sociais esmagadoras que lhes cercavam. "A época que vamos vivendo é evidentemente, no conceito de todos, uma era de transição," declarou Bello (1985, p. 185) "um mundo novo se prepara e há de surgir dessa inquietação incessante." ${ }^{.11}$ Nenhum dos autores gostava muito dessas mudanças. Bello lamentava que um verdadeiro plantador à moda antiga tinha se tornado um anacronismo, "não é mais...que uma sombra que a industrialização das terras vai apagando rapidamente.” (BELLO, 1985, p. 162) Lins do Rego encerrou o "Ciclo da cana-açúcar" com o romance Usina; apropriadamente, já que ele partilhava da opinião de Freyre de que o advento das usinas marcava o fim de uma importante época na região canavieira. Ao longo de todo o ciclo, as usinas personificam um conjunto de males morais destruidores de um modo de vida: elas consomem a terra com um apetite insaciável, destroem o balanço da vida do engenho, deslocam trabalhadores comuns e dominam a vida dos seus proprietários.

Tanto Lins do Rego quanto Bello enquadraram as transformações do seu tempo por meio dos seus efeitos na terra, ligando mudanças na estrutura social a mudanças na paisagem. A referência de Bello à industrialização da terra era um refrão frequentemente repetido e ele usava o termo para descrever todas as transformações do seu mundo, incluindo o crescimento e a dominância cada vez maior das usinas e a degradação do meio ambiente. "As próprias terras parecem protestar" contra as mudanças, pensava Bello, escrevendo que elas "se encolhem e se recusam aos novos donos como mulheres honestas a conquistadores.” (BELLO, 1985, p. 59, 162, 186, 228) Um dos protagonistas de Lins do Rego rumina sobre as mudanças iminentes após a venda do seu engenho a uma usina: 
"Amanhã, uma chaminé de usina dominaria as cajazeiras. Os paus-d'arcos não dariam mais flores porque precisavam de terra para cana. E os cabras de eito acordariam com o apito grosso da usina. E a terra iria saber o que era trabalhar para usina. E os moleques o que era fome." (LINS DO REGO, 1966a, p. 527). Fazendo a crônica do seu presente e prevendo o futuro, ambos expressavam as mudanças ambientais e sociais como um complexo multifacetado. Quando se referiam a esforços conservacionistas -Bello nas suas próprias plantações e Lins do Rego escrevendo sobre seu avô como protagonista - eles aparecem como tentativas verdadeiramente conservadoras de salvação de uma rica paisagem. ${ }^{42}$

Assim como ocorre com Freyre, muitos dos significados que Lins do Rego e Bello associam a essa paisagem contêm postulados sobre raça, gênero e poder. Suas meditações sobre as mudanças no meio ambiente são inseparáveis da sua perspectiva em relação à estrutura social, que incluía pressupostos sobre raça e gênero. Em Fogo Morto (2002, p. 220-223), por exemplo, Lins do Rego descreve o senhor de engenho Capitão Tomás, uma vez poderoso e vital, adoecendo de desespero por causa de uma filha doente. A fuga de um escravo do engenho de Tomás o reaviva, e ele se engaja numa perseguição vigorosa e obstinada. Informado de que o escravo buscou refúgio no engenho de outro homem, Tomás tem uma interação humilhante com o senhor insolente. Após o retorno do escravo, ele extravasa sua frustração ordenando uma punição severa. ${ }^{43} \mathrm{O}$ episódio demonstra os vínculos entre masculinidade e a visão de mundo do plantador ao retratar a injeção de energia que Tomás vivencia quando se mobiliza para perseguir o escravo fugitivo e na batalha de vontades senhoriais entre Tomás e o seu rival recalcitrante. O que está em jogo nessa confrontação é o poder de mando masculino.

Nas suas memórias, Lins do Rego (1957 [1956], p. 313) descreve uma amizade com o cavalariço do seu avô, um menino que lhe fez dar-se conta de "que a vida dos brancos só era grande porque havia os negros." Mas Lins do Rego (1957 [1956], p. 331-332, 335-342) via o jovem mais com curiosidade do que com qualquer outra coisa, um "negro abandonado" cheio de observações sagazes sobre o mundo, mas nunca um igual. Mesmo essa modesta reflexão sobre a política racial da zona canavieira merece destaque, e a sua qualidade distingue Lins do Rego e Bello de Freyre. Ambos questionaram seu próprio lugar na hierarquia de poder que colocava os proprietários de terra brancos acima dos trabalhadores negros. "Entre tantos homens era eu o Senhor, quando poderia muito mais facilmente, pela lei das probabilidades, ser um deles," Bello escreveu (1985, p. 161), perguntando-se retoricamente, "Por que esse capricho do Destino?". Lins do Rego escreveu um romance inteiro da perspectiva de um garoto afrodescendente pobre (Moleque Ricardo) indicando uma disposição para abordar desigualdades sociais. Mesmo o seu personagem mais frequentemente recorrente, Carlos, reflete que "os livros começavam a me ensinar a ter pena dos pobres" como aqueles da fazenda do seu avô. (LINS DO REGO, 1966b, p. 220).

Um livro posterior descarta bruscamente esses devaneios, quando o narrador de Lins do Rego (1948, p. 125) reconhece que é "muito bom um sujeito qualquer, cheio de conforto, cheio de todas as vantagens, desejar a felicidade dos pobres, que viviam como porcos. Puro disfarce, malandragem.”. Bello também encontra uma solução conversadora para a sua divagação sobre a "lei das probabilidades." Após um percurso de busca espiritual, ele destaca como as antigas famílias canavieiras de Pernambuco eram talhadas para o exercício do poder. Os trabalhadores, ele sustenta, não respondiam com respeito aos novos plantadores. A hesitação e a autoconsciência de Bello e Lins do Rego sobre o seu poder derivava provavelmente da ansiedade sobre as implicações das mudanças sociais que ocorriam no período, já que os dois autores louvavam os tempos passados. Descrevendo a decadência do poder e do status senhoriais, Bello lamentava $(1985,162 ; 179)$ que o engenho já "não era aquilo mais a miniatura de um reinado, e sim já a miniatura de seu próprio passado." 
Ambos os autores concluem seus questionamentos com comentários que naturalizam as relações de poder. Bello reconhece que poucas coisas lhe interessavam tanto "como ver um velho escravo dos raros que subsistem." "Vendo-os recordo com íntima saudade aqueles que conheci, criança", continua ele "atrelados ao serviço do engenho como bois e burros." (BELLO, 1985, p. 217). Carlos, o protagonista de Lins do Rego observa sobre os trabalhadores do seu avô: "O costume de ver todo dia esta gente na sua degradação me habituava com a sua desgraça... Achava muito natural que vivessem dormindo em chiqueiro, comendo um nada, trabalhando como burros de carga." $\mathrm{O}$ uso repetido da palavra "natural" sublinha um ponto fundamental da visão de mundo dos plantadores: o pressuposto de que o seu poder perpassa os trabalhadores e se estende sobre o mundo natural.

O romancista torna isso ainda mais claro no resto da passagem. "A minha compreensão da vida fazia-me ver nisto uma obra de Deus," ele continua, "eles nasceram assim porque Deus quisera, e porque Deus quisera nós éramos brancos e mandávamos neles. Mandávamos também nos bois, nos burros, nos matos?" (LINS DO REGO, 1986, p. 134). Lins do Rego dificilmente poderia ter sido mais explícito em descrever a visão de mundo dos plantadores em relação à paisagem produtiva sobre a qual eles reinavam. Essa passagem também destaca o relevo crucial da cor, demonstrando as continuidades com a escravidão de base racial. Deus quis que o narrador e a sua família nascessem brancos para governar sobre eles, - os trabalhadores - que se presume serem afrodescendentes.

Para Bello, a visão de um velho escravo lhe recordava dos dias em que a ordem social, incluindo o cativeiro dos escravos africanos, estava intacta. Mas a "industrialização" da terra tornou algumas práticas agrícolas obsoletas, junto com as relações sociais que elas estruturavam. O controle dos antigos plantadores sobre suas terras e trabalhadores integrava todos esses elementos em um equilíbrio precário. À medida que o poder dos antigos senhores em relação aos novos usineiros se erodia, Bello e Lins do Rego temiam que o mesmo ocorresse com o equilíbrio "natural" da região canavieira. Os trabalhadores e a terra eram degradados conjuntamente pela nova, moderna e eficiente indústria. As muitas referências à destruição trazida pela indústria açucareira moderna mecanizada e às qualidades superiores da natureza formam parte do que Luciano Trigo denomina a "visão ecológica” de Lins do Rego. Mas, alerta Trigo (2002, p. 218-219), essa perspectiva é mobilizada a serviço da "idealização da ordem oligárquica, camuflada pela celebração da sua integração com a natureza." O interesse real de Lins do Rego e Bello jaz na ressurreição de uma estrutura social em desintegração. Eles amavam a terra porque, como lembrava Bello, "a terra conferia foros de nobreza." (BELLO, 1985, p. 179).

Os plantadores e contemporâneos de Lins do Rego que posteriormente se reconheceram nos seus livros revelavam talvez a mais verdadeira evidência da sua relevância para a visão de mundo da elite. Mesmo Francisco Julião, que se tornou um importante líder das Ligas Camponesas ao final dos anos 1950, mas que nasceu de uma família de proprietários de terra, destacou: "guardo aquelas imagens de menino de engenho, porque foi onde vivi, nasci, e cresci." "Foi uma infância que encontro nos livros de José Lins do Rego e em outros que escreveram sobre o Nordeste, a cana-deaçúcar e os canaviais." ${ }^{\prime 4}$

\section{Paisagens produtivas: conceituando a visão de mundo da elite}

A paisagem produtiva era um conceito portátil, comunal e durável; era visto em mais de um lugar, compartilhado por mais de uma pessoa e persistente ao longo do tempo. As paisagens construídas do século XVII europeu, designadas para complementar uma casa de campo, eram inerentemente únicas. (COSGROVE, 1985, p. 55-56). Mas esse não era o caso da paisagem produtiva como vista 
na zona canavieira, do rio Persinunga ao rio Paraíba. Pode ser que novas pesquisas demonstrem a aplicabilidade do conceito no Caribe e em outras áreas açucareiras ou lugar de denso cultivo na forma de plantation. As conexões entre as ideias de Nabuco, as teorias de Freyre, a ficção de José Lins do Rego e as memórias de Júlio Bello demonstram consistência e elementos comuns nessa visão de mundo da elite. Além do mais, a continuidade de perspectiva entre a geração de Nabuco e a de Freyre implica estabilidade, uma característica vinculada ao mecanismo do habitus. O habitus do plantador girava em torno do mando e da autoridade. $\mathrm{O}$ mando ou o que pode ser descrito como o "poder de comandar," era reforçado por meio da violência. ${ }^{45}$

Nabuco e posteriormente, Bello, Freyre, e Lins do Rego, acompanharam mudanças sociais e econômicas que eles viam com desconforto. Eles descreveram o declínio de uma ordem rural patriarcal benevolente e a ascensão do capitalismo impessoal. (NABUCO, J., 1981 [1900]., p. 132; FREYRE, 1963b, p. 131). Nabuco observou a experimentação inicial com os grandes "engenhos centrais" enquanto os demais testemunharam a consolidação da dominação da usina. Apreensão e temores marcaram o período inicial, enquanto profundo desgosto e nostalgia marcaram o segundo. Mas ambos os períodos partilharam de um discurso comum, que ligava a terra e o trabalho num todo único, orientado pela produção e pelo prestígio e que não reconhecia distinção clara entre os combustíveis naturais e humanos que alimentavam a produção de açúcar. ${ }^{46} \mathrm{Em}$ acréscimo, Freyre e Nabuco compartilhavam da crença na nobreza do passado açucarado de Pernambuco e no filistinismo do novo futuro sulista e industrial do Brasil. Esse antagonismo regional resultou em parte de noções conflitantes, crescentemente divergentes, sobre a terra e o trabalho. Os nordestinos, porém, tinham em comum com seus pares sulistas o fato de se assentarem sobre a escravidão africana.

Nabuco descreveu como a visão de mundo de um plantador girava em torno do poder de mando que se espalhava ao redor do seu lar institucional situado na escravidão. "O nosso caráter, o nosso temperamento, a nossa organização toda, física, intelectual e moral, acha-se terrivelmente afetada pelas influências com que a escravidão passou trezentos anos a permear a sociedade brasileira," escreveu ele em O Abolicionismo (1977b, p. 60), e "a empresa de anular essas tendências é superior, por certo, aos esforços de uma só geração." A sociedade teria que enfrentar o racismo, continuava ele, assim como eliminar "a lenta estratificação de trezentos anos de cativeiro, isto é, de despotismo, superstição e ignorância." (NABUCO, J.,1977b, p. 59) ${ }^{47}$ Nabuco insistia que a palavra escravidão deveria ser compreendida "em sentido lato... significa muito mais: a soma do poderio, influência, capital e clientela dos senhores todo ...[assim como] o espírito, o princípio vital que anima a instituição toda." (NABUCO, J.,1977b, p. 60). Nabuco via esse poder de mando, que se estendia das relações entre senhores e escravos para as relações entre patrono e clientela, como a raiz maligna dos problemas do país, não apenas como alicerce da instituição legal da escravidão. "Não há como negar o influxo desse fiat: [...] 'o Poder é o Poder," escreveu ele, "é toda a nossa história." (NABUCO, J., 1977b, p. 65; NABUCO, J., 1977a, p. 11; 17).

Essa história não acabou com o fim da escravidão, por certo. A fórmula "o poder é o poder" continuou a ser verdadeira, assim como ocorreu com as normas de coerção, discriminação e prepotência que a acompanhavam. A despeito da abolição da escravidão, os trabalhadores labutavam sobre aquilo que Denise Soares de Moura descreveu (1998, p. 100) como "a herança cultural paternalista brasileira, associada à violência e às relações personalizadas de poder." Continua Moura no seu estudo sobre os libertos nos últimos dias da escravidão em São Paulo: "o mandonismo latente nos sentimentos dos senhores se espraiava pela relação de trabalho" às vezes, e muito além delas, podemos acrescentar. (MOURA, 1998, p. 141, grifo nosso). Esse raciocínio era tão ou mais aplicável às atitudes em relação a poder e mando em Pernambucano. 


\title{
NOTAS
}

\author{
${ }^{1 *}$ Emory University
}

${ }^{1}$ A centralidade do mando aparece repetidamente nos escritos de acadêmicos e observadores da zona canavieira de Pernambuco. Carlos Mota (1994, p. 55) descreve a contradição entre a "perspectiva modernizante" do desenvolvimento capitalista no começo do século XX e o "mandonismo do senhor de engenho." O crítico literário Sérgio Milliet, escrevendo sobre um plantador em um romance de Lins do Rego, descreve o "gozo tranquilo do mandonismo e da riqueza." Freyre capturou a sutileza e a centralidade do mando em um ensaio sobre as mudanças em Pernambuco ao longo do século que precedeu 1925. Ele citou um plantador de meados do século XIX que afirmava serem os proprietários da plantation atados às terras "como as ostras ao rochedo." O elo que os unia, Freyre argumentava, era "a tarefa de mandar." Ao contrário do domínio fácil exercido pelos “milionários de hoje," o plantador de cana necessitava aplicar constante atenção e ação. Freyre descreve (1941, p. 175-176) os plantadores dirigindo os escravos nos campos "falando duro a negros enormes armados com facões e machados - e eles sem arma alguma"... "certos do prestígio da voz e do gesto." Eles não eram apenas ligados à terra como "ostras ao rochedo"; eles se sustentavam no poder que a terra proporcionava. Eles habitavam e corporificavam aquele poder, assumindo que suas vozes e gestos transmitiriam sua autoridade.

Gregório Bezerra, que posteriormente se tornaria um importante organizador do Partido Comunista na zona canavieira, relembra em suas memórias experiências de infância numa plantation pouco depois da virada do século $\mathrm{XX}$. Suas memórias confirmam os contornos da sociedade dirigida pelo patriarcalismo e pela patronagem evocada por Nabuco, Freyre, Lins do Rego e Bello. O domínio dos plantadores seguia inquestionável e a ele tudo se subordinava. O jovem Bezerra se espantou com a aparência belicosa do homem forte da plantation, Pelegrino, que carregava na cintura um facão, uma adaga, um porrete e um revólver de tambor duplo. "Tinha sido escravo do senhor de engenho," escreveu Bezerra, "mas apesar de formalmente livre, permanecia na escravidão." Pelegrino "podia prender, desarmar e espancar os trabalhadores, se assim o quisesse." Suas prerrogativas eram sancionadas pela "autoridade do engenho"; ou seja, a palavra do plantador. Quando o proprietário alugou o engenho a um plantador diferente, Bezerra escreveu que "o novo ocupante era o dono da casa grande, do engenho e de tudo, inclusive dos habitantes." (BEZERRA, 1980, p. 3435, 46, 51). Essa afirmação de uma realidade de fato vista da perspectiva de um trabalhador empobrecido oferece um paralelo à citação das memórias de Lins do Rego com as quais iniciamos este artigo; ambas evocam o poder avassalador do plantador. ${ }^{49}$ Tanto Bezerra quanto Lins do Rego integram explicitamente a natureza humana e a não humana sob a dominação do plantador.

A referência de Bezerra à continuidade da subordinação do ex-escravo Pelegrino também aponta para a continuidade nas concepções raciais na zona canavieira. Elas não eram separáveis das ideias sobre trabalho e sobre a terra. Escorregadias como são as categorias de raça e classe nessa área, havia uma intersecção presumida entre trabalhadores e negritude. Isso emerge claramente de um curto ensaio publicado em 1934 por um afro-brasileiro chamado Jovino da Raiz que comparava o "trabalhador negro" sob o velho regime da plantation e sob o novo regime dominado pela usina. Ao longo do seu texto de quatro páginas, da Raiz (1988, p. 191-194) tomava os termos "negro" e "trabalhador" como sinônimos perfeitos. Em Nordeste, Freyre descreve a naturalização dessa fusão como uma extensão do domínio da cana "sobre o preto, o roxo ou o vermelho dessa terra crua." Com a ascensão da cana-de-açúcar, segundo ele, "a natureza do Nordeste" mudou e desenvolveram-se:

Relações de extrema ou exagerada subordinação: de umas pessoas a outras, de umas plantas a outras, de uns animais a outros; da massa inteira da vegetação à cana imperial e todopoderosa; de toda a variedade de vida humana e animal ao pequeno grupo de homens brancos-ou oficialmente brancos--donos dos canaviais, das terras gordas, das mulheres bonitas, dos cavalos de raça. Cavalos de raça tantas vezes tratados melhor que os trabalhadores da bagaceira. (FREYRE, 1989[1937], p. 75).

Ao mesmo tempo em que reconhece esse desequilíbrio nas relações de poder, inclinado pesadamente em favor dos brancos ricos, Freyre amontoa essa desigualdade com uma série de outras que caracterizariam o mundo da cana. A cana subjuga as outras plantas, os plantadores subjugam outras pessoas. A decorrência é que a posição inferior dos 
trabalhadores negros refletia um ordenamento inexorável (se não completamente "natural") do mundo, ligado aos processos ambientais.

A lógica por meio da qual os membros da classe dominante experimentavam e exerciam poder se originava nas práticas de interação social forjadas sob a escravidão. Os proprietários não se apegavam à ficção legal da propriedade, seja de terra ou de escravos. Ao invés disso, na prática cotidiana das suas vidas guiadas pelo seu habitus de classe eles exerciam as prerrogativas de mando que o seu poder lhes autorizava. Pierre Bourdieu não oferece uma definição sintética, mas ele se refere ao habitus como "um sistema socialmente constituído de estruturas cognitivas e motivacionais." Ele avança descrevendo-o como "esquemas de percepção e apreciação" que formam um princípio organizado que se revela apenas em ações. ${ }^{50}$

No seu momento mais revelador, Bourdieu (1977, p. 78) denomina o habitus "história transformada em natureza." Quer dizer, os indivíduos absorvem as predisposições, compreensões, sistemas de significado e hábitos do seu grupo social particular e da estrutura social mais abrangente, todos eles elementos constituídos ao longo do tempo. "Os indivíduos carregam com eles, em todos os momentos e lugares," escreveu Bordieu, "suas posições presentes e passadas na estrutura social.” Por essa razão, Bourdieu insiste que as relações “interpessoais’ nunca são, a não em aparência, relação indivíduo-a-indivíduo e... a verdade das interações nunca está contida completamente na interação” porque cada indivíduo carrega consigo disposições culturais acumuladas. O habitus abrange não apenas as formas de pensar sobre o mundo, mas se inscreve nos corpos dos indivíduos, definindo as formas como eles ficam em pé, caminham e impõem sua dominação. (BOURDIEU, 1977, p. 82; 81; 15; grifo nosso). Com cerca de quatro séculos de escravidão estruturando seu habitus, a visão de mundo e o comportamento dos plantadores dominavam as relações sociais e as percepções individuais mesmo após o final da escravidão.

Como o seu acesso ao controle total lentamente começou a erodir as transformações econômicas, a elite reagiu com aguda nostalgia. Isso explica a poderosa atração da infância evidenciada pelos autores estudados aqui. Nabuco (1981 [1900], p. 129) escreveu em sua autobiografia: "o traço todo da vida é para muitos um desenho da criança esquecido pelo homem, mas ao qual ele terá sempre que se cingir sem o saber." Na sua introdução à autobiografia de Nabuco, Freyre manifesta o seu desejo de que o velho político tivesse incluído mais sobre a sua infância, escrevendo que apesar do alto valor dado pelo abolicionista à juventude suas memórias careciam de "nostalgia do passado." (FREYRE, 1977, p. 8) Por sua parte, Lins do Rego (1957 [1956], p.5) registrou as memórias dos seus "verdes anos" a fim de "reter tudo o que ainda me resta daquela 'aurora' que... é a nostalgia." Essa obsessão com a infância reflete mais do que uma saudade persistente do passado pessoal; ela também representa a nostalgia de um passado coletivo. ${ }^{51}$

O conceito de habitus torna-se mais útil ainda por meio da reversão de uma das fórmulas de Bourdieu. O processo que se operava na zona canavieira pode ser percebido não apenas como a história se transformando em natureza, mas também como a natureza se transformando em história. Os modos como a elite tomou a "natureza" em torno de si e a incorporou numa história particular estruturou suas memórias do meio ambiente e sua disposição em relação aos elementos da sua história pessoal. Eles integraram aos canaviais que os cercavam a história do seu próprio poder naturalizado e do seu jugo sobre os trabalhadores afrodescendentes e sobre o meio ambiente. O poder opera por meio da "natureza" assim como ele opera por meio da raça, da classe e do gênero, já que as mudanças ambientais e os efeitos dos constrangimentos ambientais sobre os seres humanos têm consequências que atingem as sociedades em íntima vinculação com os diferenciais de poder. ${ }^{52} \mathrm{~A}$ extensão do poder da elite no meio ambiente ocorria por meio do corpo dos seus trabalhadores e assim os unia em um todo na memória da elite. Ao naturalizar esse estado de coisas, a elite também projetou essa visão sobre os seus trabalhadores. Bello (1985, p. 39), por exemplo, escreveu que os ex-escravos "ficaram nos eitos respeitando o branco e servindo-o," após a abolição, demonstrando quase a mesma "humildade que o hábito e o atavismo lhes haviam ensinado." 53 Já que eles ficaram trabalhando na plantation, concluía Bello, aqueles ex-escravos tinham reconhecido sua posição natural.

A paisagem tornou-se o repositório natural para uma compreensão compartilhada de autoridade. A "natureza", ou o espaço do canavial, tornou-se o veículo de significados compartilhados, uma corporificação espacial de um passado coletivo. Esses significados incluíam o pressuposto do poder do plantador, assim como o exercício daquele poder por meio da violência. A elite expressava sua nostalgia por um mundo que se foi como nostalgia por um lugar porque o que ela lamentava era a perda da paisagem — um ambiente estratificado por um conjunto de postulados e concepções — que caracterizavam o mundo dos engenhos. ${ }^{54}$ Essa paisagem era, como situa Simon Schama, (1995, p. 7) "uma obra da mente. Seu cenário construiu-se tanto de extratos de memória quanto de camadas de rocha.” O fato que a elite não 


\section{ROGERS, T. D.}

era nostálgica em relação ao um ambiente físico em particular fica claro nos vários modos como os velhos senhores de fato se distanciavam daquele ambiente. O ex-plantador Henrique Milet escreveu (1989, p. 85) em 1878 que todo o seu aprendizado livresco sobre a agricultura canavieira era inferior ao conhecimento dos "matutos" que "conheciam-nas melhor a olho, pela natureza dos produtos espontâneos do solo, do que eu com os meus ensaios e experimentações." Havia um aspecto territorial definitivo nas vidas das famílias de plantadores e um aspecto territorial no seu lamento pelas tradições que se formam, mas não havia delicadeza na sua relação com o meio ambiente. O que eles proclamavam como amor telúrico não era uma paixão pela natureza ou candura pelas dinâmicas de exploração racial, classista e ambiental que constituíam a paisagem produtiva da zona canavieira.

${ }^{2} \mathrm{~A}$ "zona canavieira" à qual nos referimos ao longo deste texto é a região produtora de açúcar de Pernambuco. Embora esse termo seja usado ocasionalmente na própria região, de longe o termo mais comum é "zona da mata", que se refere a uma faixa de terra baixa e abundante em água - estendendo-se $100 \mathrm{~km}$ para dentro do continente - e que tem sido utilizada tradicionalmente à produção de açúcar.

${ }^{3} \mathrm{O}$ autor agradece ao revisor anônimo da Luso-Brazilian Review, na qual a versão original deste texto foi publicada, pelos insights sobre os pontos destacados neste parágrafo e pela forma como essas ideias se desenvolveram no restante do texto.

${ }^{4}$ Thomas Greider e Lorraine Garkovich definem paisagem simplesmente como "o ambiente simbólico criado pelos atos humanos de conferir significado à natureza e ao meio ambiente, de dar ao ambiente definições e formas de um ângulo particular de visão e por meio de um filtro especial de valores e crenças." GREIDER, Thomas; GARKOVICH, Lorraine. "Landscapes: The Social Construction of Nature and the Environment," Rural Sociology 59, no. 1, 1994, p. 1. Embora seja muito boa, essa perspectiva ignora o peso histórico que ecoa em associação com o termo. A história da palavra inclui tonalidades de descrição e criação. Cosgrove escreve que a paisagem está conectada "com o levantamento e mapeamento das fazendas comerciais recentemente adquiridas, consolidadas e 'aperfeiçoadas' em mãos da burguesia urbana... Ao pintar e ajardinar, o design de paisagens realiza visual e ideologicamente... o controle e dominação sobre o espaço como uma entidade absoluta, objetiva, sua transformação em propriedade do indivíduo ou do Estado." COSGRONE, Denis. "Prospect, Perspective and the Evolution of the Landscape Idea," Transactions of the Institute of British Geographers 10, 1985, p. 46. Ver também SHORT, John Rennie. Imagined Country: Society, Culture and the Environment. New York: Routledge, 1991, p. 6; BASSO, Keith H. Wisdom Sits in Places: Landscape and Language Among the Western Apache (Albuquerque: University of New Mexico Press, 1996).

${ }^{5}$ Com relação à influência da paisagem da elite nos eventos políticos do século $\mathrm{XX}$, incluindo os grandes conflitos com os movimentos operários e camponeses dos anos 1950 e 1960. Ver ROGERS, Thomas D. The Deepest Wounds: The Laboring Landscapes of Sugar in Northeast Brazil. Chapel Hill: The University of North Carolina Press, 2010.

${ }^{6}$ Essa abordagem ainda está se desenvolvendo na literatura histórica, com a maioria do trabalho sobre paisagens emanando da geografia e da antropologia. As metodologias históricas têm muito a oferecer nesse campo. Para um trabalho recente fascinante de um antropólogo, ver RAFFES, Hugh. In Amazonia: A Natural History. Princeton: Princeton University Press, 2002.

${ }^{7}$ Dean escreveu que pretendia que seu livro fosse "uma memória da destruição" da Mata Atlântica.

${ }^{8}$ Wakefield escreveu em 1829 A Letter From Sydney, que influenciou em muito as políticas de colonização australianas.

${ }^{9}$ Escravos, escreveu Freyre, eram "moedas de carne, todos eles, moedas que sendo prontamente corruptíveis e sujeitas à decadência, constituíam uma variedade incerta e instável de capital.” Gilberto Freyre, Casa-Grande e Senzala: Formação da Família Brasileira sob o Regime de Economia Patriarcal, 14th Ed. Recife: Imprensa Oficial, 1966, p. 170, tradução de Freyre, The Masters and the Slaves: A Study in the Development of Brazilian Civilization, 2d English ed, Samuel Putnam, trans. New York: Alfred A. Knopf, 1963b, p. 177. Há um ditado na Paraíba que brinca como o nome da família Pessoa, que dominou o estado por longo tempo: "Na Paraíba, quem não é Pessoa é coisa". ANDRADE, Manuel Correia de. Modernização e Pobreza: A Expansão da Agroindústria Canavieira e seu Impacto Ecológico e Social. São Paulo: Editora da Universidade Estadual de São Paulo, 1994, p. 165. 
${ }^{10}$ Podia-se perceber esse desenvolvimento do declínio da indústria açucareira, numa espiral descendente, desde o seu auge no século XVII.

${ }^{11}$ O comentário sobre o "amor da rotina" veio da resposta da Comissão Agrícola de Pernambuco a um questionário colocado em circulação pelo Ministério da Agricultura Imperial. Opunha-se a essa ideia MILET, Henrique Augusto, que descreveu suas posições em A Lavoura da Cana de Açúcar (Recife: Editora Massangana, 1989 [1881]), p. 84.

${ }^{12}$ Por exemplo, o geógrafo Mário Lacerda de Melo escreveu um artigo entitulado "Agricultural and Industrial Problems of Sugar in Pernambuco," no qual ele classificava a "reorganização do trabalho rural" como o problema agrícola mais importante da região. MELO, Mario Lacerda de. "Problemas Agrícolas e Industriais do Açúcar em Pernambuco," Brasil Açucareiro 28, no. 6, 1946, p. 52.

${ }^{13}$ Devemos notar o uso comparativo que Nabuco faz da África aqui. Ele situa o continente como o locus por excelência do atraso, expressão da ausência completa de modernidade. E ele podia estar jogando com as ansiedades dos seus colegas, que sabiam muito bem que a maior parte dos habitantes do país era africana ou afrodescendente. Deve notarse também que a escravidão podia ser o problema da época, mas a seca era o problema do momento para os pares nordestinos de Nabuco. Esse era o tempo em que a região estava sofrendo a Grande Seca (1877-1879).

${ }^{14}$ José Pádua mostra que o pensamento do século XIX permanecia num padrão anterior, que via a degradação ambiental como o preço do atraso. Foi apenas no século XX que uma nova ideia prevaleceu: que a degradação ambiental era o preço do progresso. PÁDUA, José Augusto. “'Cultura esgotadora': agricultura e destruição ambiental nas ultimas décadas do Brasil Império," Estudos de Sociedade e Agricultura 11, 1998, p. 158; DUARTE, Regina Horta. "Por um pensamento ambiental histórico: O caso do Brasil," Luso-Brazilian Review 41, no. 2, 2005, p. 151. "É impossível entender a ecologia política do século XVII e XVIII no Brasil," escreve Pádua na página citada, "sem reconhecer a identificação entre modernização tecnológica e a superação do desastre ecológico."

${ }^{15}$ A distância experimentada por Nabuco em relação à região canavieira tem paralelo na vivida por Freyre (ver abaixo).

${ }^{16}$ Ver também a tradução levemente distinta deEISENBERG, Peter. The Sugar Industry in Pernambuco: Modernization Without Change, 1840-1910, Berkeley: University of California Press, 1974, p. 176.

${ }^{17}$ Sérgio Milliet chamaria isso de "satisfação pacífica do mandonismo e da riqueza." MILLIET, Sérgio. “A Obra de José Lins do Rego,” in José Lins do Rego, Fogo Morto, 6ª edição (Rio de Janeiro: José Olympio, 1965 [1943]), p. xx.

${ }^{18}$ Uma literatura substancial em geografia, antropologia e história aborda a categoria de "lugar." Para alguns exemplos, ver TUAN, Yi-Fu. "Place: An Experiential Perspective," The Geographical Review 65, no. 2, 1975, p. 151-165; CASEY, Edward S. The Fate of Place: A Philosophical History. Berkeley: University of California Press, 1997.

${ }^{19}$ Essa citação serviu de inspiração para Caetano Veloso, que incluiu as palavras na letra de uma canção no seu álbum de 2001 Noites do Norte (Nonesuch). Numa biografia do seu pai, Carolina Nabuco se referiu a essas passagens como sendo "prenhes de poesia... da instituição que [Nabuco] estava destinado a combater." NABUCO, Carolina, The Life of Joaquim Nabuco, trans. Ronald Hilton. Stanford: Stanford University Press, 1950, p. 8. O tom saudoso da passagem pode ser explicado pelo momento da escrita, quando Nabuco vivia em Londres semiexilado da República em relação à qual nutria sentimentos ambivalentes.

${ }^{20}$ Mota traz um argumento similar. Ver MOTA, Carlos Guilherme. Ideologia da Cultura Brasileira, 1933-1974, 9ª ed. (São Paulo: Editora Ática, 1994, p. 55).

${ }^{21}$ Um biógrafo nota que Freyre foi uma criança urbana, embora ele tenha passado férias numa fazenda canavieira aos nove anos de idade. CHACON, Vamireh. Gilberto Freyre: Uma Biografia Intelectual. Recife: Editora Massangana, 1993, p. 37. 
${ }^{22}$ FREYRE, Gilberto "Preface to the First English-Language Edition of The Masters and the Slaves," in The Masters and the Slaves: A Study in the Development of Brazilian Civilization, second English-language edition, translated by Samuel Putnam (New York: Alfred A. Knopf, 1963), p. xi.

${ }^{23}$ Durval Muniz de Albuquerque Jr., Joedna Meneses, e Stanley Earl Blake destacam a década de 1920 como o momento em que o Nordeste emergiu como uma unidade coerente e reconhecida. ALBUQUERQUE Jr, Durval Muniz de. A Invenção do Nordeste e Outras Artes. Recife: Editora Massangana, 1999; GREENFIELD, Gerald. The Realities of Images. Imperial Brazil and the Great Drought (Philadelphia: American Philosophical Society, 2001). BLAKE, Stanley Earl. "The Invention of the Nordestino: Race, Region, and Identity in Northeastern Brazil, 1889-1945," Ph.D. Dissertation, SUNY-Stony Brook, 2001; MENESES, Joedna Reis de. "A Indústria do Atraso ou O Atraso da Indústria? O Discurso da Industrialização no Nordeste 1950-1970,” Dissertação de Mestrado, Universidade Federal de Pernambuco, 1999.

${ }^{24}$ Gilberto Freyre, "Introdução à 9 ${ }^{a}$ Edição," NABUCO, Joaquim. Minha Formação (Brasília: Editora Universidade de Brasília, 1981 [1900], p. 11).

${ }^{25}$ É característico da produção acadêmica sobre Freyre que após mencionar esses dois fatores Skidmore não diga nada sobre determinismo climático ou ambiental, focando ao invés disso na questão racial.

${ }^{26}$ Freyre também defendeu a urgência de superação dessa visão, especificamente no caso do Brasil, "porque ela é um exemplo do qual os alarmistas fazem muito uso ao lamentarem a mistura de raças e a malignidade dos trópicos em apoio da suas teses de que a degeneração do homem é um efeito do clima ou da miscigenação." Freyre está longe de ter sido a primeira pessoa a desafiar esses determinismos, algo que vários acadêmicos já tinham questionado. Sidney Chalhoub, por exemplo, discute os médicos brasileiros de meados do século XIX que trabalharam contra o determinismo racial e climático. CHALHOUB, Sidney. "The Politics of Disease Control: Yellow Fever and Race in Nineteenth Century Rio de Janeiro," Journal of Latin American Studies 25, no. 3, 1993, p. 455.

${ }^{27}$ Deixando claros os seus débitos intelectuais, numa introdução à autobiografia de Nabuco, Freyre laudou tanto Nabuco quanto da Cunha pelo seu reconhecimento perspicaz da conexão entre homem e terra. Mas embora os escritos dos dois homens trouxessem a paisagem à página de forma similar, Freyre argumentava que Nabuco tinha ainda mais "vigor terrestre" do que da Cunha Gilberto Freyre, "Introdução à 10a Edição," in Joaquim Nabuco, Minha Formação (Brasília: Editora Universidade de Brasília, 1981, p. 20).

${ }^{28}$ As citações desses acadêmicos nas obras de Freyre são numerosas demais para serem mencionadas, mas para um engajamento mais amplo com alguns deles, ver FREYRE Gilberto, The Masters and the Slaves: A Study in the Development of Brazilian Civilization, 2nd English ed, Samuel Putnam, trans. New York: Alfred A. Knopf, 1963, p. 15, 17, 297, 330. Semple e Sauer ensinavam geografia no conhecido programa da Universidade da Califórnia em Berkeley. Thomas Griffith Taylor escreveu Thomas Griffith Taylor Environment and Race: A Study of the Evolution, Migration, Settlement and Status of the Races of Man (London: Oxford University Press, 1927). E Freyre estudou com o eminente antropólogo Boas na Universidade Columbia.

${ }^{29}$ O livro foi reeditado e revisado dez vezes até 1948, após a sua primeira aparição em 1915.

${ }^{30}$ Freyre usou o termo "civilização do açúcar" na sua introdução à autobiografia de Nabuco. Freyre, "Introdução à 9 Edição," 10.

${ }^{31}$ Oton Bezerra de Melo, em um artigo de 1940 da Folha da Manhã, escreveu sobre "sete mil homens que mourejam de sol a sol." Reeditado em O Homem e a Terra na Usina Catende (n.p.: 1941).

${ }^{32}$ Freyre apontou para os padrões da cultura Ibérica como as raízes do horror dos portugueses pelo trabalho manual. Era uma tendência reforçada pelo uso do trabalho escravo africano.

${ }^{33}$ Outra reverberação das referências de Nabuco a cicatrizes na terra e na sociedade aparece em Freyre na qual ele menciona "as duas feridas sangrentas da monocultura e da escravidão, duas bocas escancaradas 
clamando por dinheiro e negros." FREYRE, Gilberto. The Mansions and the Shanties: The Making of Modern Brazil, trans. Harriet de Onís, intro. Frank Tannenbaum. New York: Alfred A. Knopf, 1963, p. 11

${ }^{34}$ Freyre obviamente representa um caso excepcional de profunda curiosidade e exposição intelectual dentre a elite pernambucana. Mas, subjacente à questão levantada por Lins do Rego é importante ter em mente que esses textos demonstram um grau muito mais elevado de reflexão, reflexividade e auto-consciência do que seria considerado "normal" para um senhor do período. Acredito que o meu argumento - de que esses textos representam articulações de um discurso sobre terra e trabalho comum a uma classe - permanece válido.

${ }^{35}$ BELLO, Júlio. Memórias de um senhor de engenho - Pref. Gilberto Freyre and José Lins do Rego - 3rd ed. (Recife, FUNDARTE, 1985), xiv.

${ }^{36} \mathrm{Na}$ sua introdução à coleção de ensaios de Freyre publicados como Região e Tradição, Lins do Rego relembra ter sido intimado por Freyre para ir além de escrever artigos de jornal. Freyre viu "algo que lhe interessava" nas peças publicadas pelo amigo na imprensa, e assim, Lins do Rego continua, "minha educação com o mestre do meu tempo começou sem que eu percebesse as lições." Ele começou imitando o estilo de Freyre antes de desenvolver o seu lentamente. LINS DO REGO, José. "Notas sobre Gilberto Freyre," in Freyre, Região e Tradição, p. 10. O próprio Freyre tinha consciência da sua influência sobre Lins do Rego. Um registro do final de 1925 no seu diário diz: "J. L. do R. [José Lins do Rego], assim como [Olívio Montenegro?], e A. F. [Alfredo Freyre?] tem me imitado - eles dentre outros de menor estatura - meu estilo, minha forma, mesmo a minha pontuação. Eu sei que eu tenho um estilo ou uma forma que se define parcialmente pela pontuação." FREYRE, Gilberto Tempo Morto e Outros Tempos: Trechos de um Diário de Adolescência e Primeira Mocidade, 1915-1930. Rio de Janeiro: José Olympio, 1975, p. 176.

${ }^{37}$ Algumas pessoas incluem Fogo Morto no "ciclo da cana-de-açúcar". José Aderaldo Castello, que o considera a "obra síntese” da série, defende que o próprio Lins do Rego incluía Fogo Morto, a despeito de ter anunciado no prefácio de Usina que a série havia terminado. CASTELLO, José Aderaldo. “Origens e Significado de Menino de Engenho," in José Lins do Rego, Menino de Engenho, 36a Ed. Rio de Janeiro: Editora Nova Fronteira, 1986, p. 30.

${ }^{38}$ Não apenas são as descrições do engenho e as estórias que ele relembra as mesmas que as experimentadas por Carlos de Melo, mas até os nomes das pessoas na sua autobiografia são as mesmas que as utilizadas por ele na sua série de romances.

${ }^{39}$ Pernambuco faz divisa com a Paraíba ao Norte e com Alagoas ao Sul.

${ }^{40}$ Leonardo Dantas Silva, “Nota do Editor," in BELLO, 1985, vii.

${ }^{41}$ Bello referia-se parcialmente ao caos que se seguiu à Revolução de 1930, que não lhe agradava nem um pouco, assim como ocorria com Freyre. Ver também BELLO, 1985, 8vo, 232 pp., 16 photos, bds.- Pernambucana 2a. Fase, v.16, p. 182.

${ }^{42}$ Sobre o avô de Carlos de Mello, Lins do Rego escreveu que ele prevenia qualquer incursão nas suas matas, porque "seria como se alguém pedisse um pedaço da carne do seu próprio corpo". LINS DO REGO, José. Plantation Boy. New York: Alfred A. Knopf, 1966, p. 34.

${ }^{43}$ Ver também a similaridade nas dinâmicas entre essa descrição e o caso discutido por BEATTIE, Peter. The Slave Silvestre's Disputed Sale: Corporal Punishment, Mental Health, Sexuality, and 'Vices' in Recife, Brazil 1869-1879," Estudios Interdisciplinarios de América Latina y el Caribe 16, no. 1, 2005. Estou em dívida com o revisor anônimo por ter salientado esse episódio.

${ }^{44}$ Francisco Julião Arruda de Paula, entrevista Eliane Moury Fernandes, fita cassete e transcrição, Recife, 1982, CEHIBRA-Fundação Joaquim Nabuco, 1.

${ }^{45}$ Em acréscimo ao fato de desafiar a ideia de que as plantations de açúcar em larga escala e seu modelo de organização e relações de trabalho dominam completamente a sociedade de regiões majoritariamente açucareiras, B. J. Barickman trabalhou com ideologias de base classista e noções distintas de terra, embora não nos termos usados neste artigo. 
BARICKMAN, Bert Jude. A Bahian Counterpoint: Sugar, Tobacco, Cassava, and Slavery in the Recôncavo, 17801860. Stanford: Stanford University Press, 1998; Idem, “A Bit of Land Which They Call Roça': Slave Provision Grounds in the Bahian Recôncavo, 1780-1860,” Hispanic American Historical Review 74, no 4, 1994.

${ }^{46}$ Essa noção de fusão entre os combustíveis humano e natural vem de NABUCO, Joaquim. Minha Formação (Brasília: Editora Universidade de Brasília, 1981 [1900]), p. 134.

${ }^{47}$ Tradução de Nabuco, Joaquim: The Brazilian Antislavery Struggle, Robert Conrad, trans., ed.Urbana: University of Illinois Press, 1977a, p. 10-11. A metáfora geológica de Nabuco evoca muito bem a integração de questões culturais e "naturais" apontadas aqui.

${ }^{48}$ MILLIET, 1965 [1943]), xx.

${ }^{49}$ Bezerra nasceu em 1900 (assim como Freyre) e Lins do Rego em 1901. Essa experiência em particular ocorreu em 1907. BEZERRA, Gregório. Memórias, vol 1. Rio de Janeiro: Editora Civilização Brasileira, 1980, p. 51.

${ }^{50}$ Ele também o descreve como um "princípio generativo duravelmente instalado de improvisação regulada." BOURDIEU, Pierre. Outline of a Theory of Practice. Cambridge: Cambridge University Press, 1977, p. 76, 17, $18,78$.

${ }^{51}$ É interessante destacar que um argumento semelhante foi apresentado recentemente por Durval Muniz de Albuquerque Jr. (após o autor ter lidado com esses problemas de forma similar). Ele escreve: "Os escritos sociológicos de Gilberto Freyre e os escritos dos chamados romancistas da década de 1930 fazem da memória o seu principal material de trabalho. Esses romancistas se empenharam em construir um Nordeste a partir das suas memórias de infância, nas quais as formas das relações sociais que estão agora sob ameaça eram dominantes. Eles transformaram suas próprias narrativas numa manifestação de cultura popular tradicional ameaçada pelo mundo moderno e as usaram como expressões do regional." Albuquerque Jr, Durval Muniz de “Weaving Tradition: The Invention of the Brazilian Northeast," Latin American Perspectives 31, no. 2, 2004, p. 55. Como notado acima, o fio comum unindo os autores se relaciona parcialmente ao tipo de texto sob análise. Embora os argumentos aqui examinados derivem da sociologia, da história e do tratado político, há também três memórias representadas.

${ }^{52}$ Ted Steinberg oferece uma clara ilustração de como o poder e o meio ambiente interagem na mudança histórica. STEINBERG, Ted. "Down to Earth: Nature, Agency, and Power in History," American Historical Review 107, no. 3, 2002, p. 802.

${ }^{53}$ Muito como a exclamação de Nabuco sobre o perdão "santos negros" em relação aos brancos, Bello sugere que "os sentimentos trágicos de ódio e rancor não separam, nem deveriam separar, os ex-escravos do homem branco que os explorou por três séculos. Na imensa sensibilidade da sua alma, todo o seu ódio deságua e submerge completamente em caridade, se afogando". BELLO, Julio Celso de Albuquerque.. Memórias de um senhor de engenho - Pref. Gilberto Freyre and José Lins do Rego - 3rd ed.- Recife, FUNDARTE, 1985, 8vo, 232 pp., 16 photos, bds.- Pernambucana 2 a. Fase, v.16, p. 39

${ }^{54}$ Albuquerque escreve: "A nostalgia é o que sentimos quando percebemos que estamos perdendo uma parte querida do nosso próprio ser - de espaços que ocupamos como sendo nossos próprios.” ALBUQUERQUE Jr, Durval Muniz de "Weaving Tradition: The Invention of the Brazilian Northeast," Latin American Perspectives 31, no. 2, 2004, p. 42.

\section{REFERÊNCIAS}

ALBUQUERQUE JUNIOR, Durval Muniz de. A Invenção do Nordeste e Outras Artes. Recife: Editora Massangana, 1999.

Durval Muniz de "Weaving Tradition: The Invention of the Brazilian Northeast," Latin American Perspectives 31, no. 2, 2004, (p. 42-61) 
BARICKMAN, Bert Jude. A Bahian Counterpoint: Sugar, Tobacco, Cassava, and Slavery in the Recôncavo, 1780-1860. Stanford: Stanford University Press, 1998.

Bert Jude 'A Bit of Land Which They Call Roça': Slave Provision Grounds in the Bahian Recôncavo, 1780-1860," Hispanic American Historical Review 74, no 4 (1994): (p. 649-687).

BASSO, Keith H. Wisdom Sits in Places: Landscape and Language Among the Western Apache. Albuquerque: University of New Mexico Press, 1996.

BEATTIE, Peter M. "Conflicting Penile Codes: Modern Masculinity and Sodomy in the Brazilian Military 1860-1916," in Sex and Sexuality in Latin America, Donna Guy and Daniel Bouldersten, org. New York University Press, 1997.

, Peter M. “The Slave Silvestre’s Disputed Sale: Corporal Punishment, Mental Health, Sexuality, and 'Vices' in Recife, Brazil 1869-1879," Estudios Interdisciplinarios de América Latina y el Caribe 16, no. 1, 2005 ( p. 41-65).

BELLO, Julio Celso de Albuquerque. Memórias de um senhor de engenho - Pref. Gilberto Freyre and José Lins do Rego. - 3rd ed.- Recife, FUNDARTE, 1985, 8vo, 232 pp., 16 photos, bds.(Pernambucana 2a. Fase, v.16).

BEZERRA, Gregório. Memórias, vol 1. Rio de Janeiro: Editora Civilização Brasileira, 1980.

BLAKE, Stanley Earl. "The Invention of the Nordestino: Race, Region, and Identity in Northeastern Brazil, 1889-1945”. Ph.D. Dissertation, SUNY-Stony Brook, 2001.

BOURDIEU, Pierre. Outline of a Theory of Practice. Cambridge: Cambridge University Press, 1977.

CARVALHO, José Murilo de. "Modernização Frustrada: A Política de Terras no Império," Revista Brasileira de História 1, 1981.

CASTELlO, José Aderaldo. "Origens e Significado de Menino de Engenho," in José Lins do Rego, Menino de Engenho, 36a Ed. Rio de Janeiro: Editora Nova Fronteira, 1986.

CASEY, Edward S. The Fate of Place: A Philosophical History. Berkeley: University of California Press, 1997.

CAULFIELD, Sueann. In Defense of Honor: Sexual Morality, Modernity, and Nation in EarlyTwentieth-Century Brazil. Durham: Duke University Press, 2000.

CHACON, Vamireh. Gilberto Freyre: Uma Biografia Intelectual. Recife: Editora Massangana, 1993.

CHALHOUB, Sidney. "The Politics of Disease Control: Yellow Fever and Race in Nineteenth Century Rio de Janeiro,” Journal of Latin American Studies 25, no. 3, 1993. 
ROGERS, T. D.

COSGROVE, Denis. "Prospect, Perspective and the Evolution of the Landscape Idea," Transactions of the Institute of British Geographers 10, 1985.

COSTA, Emilia Viotti da. The Brazilian Empire: Myths and Histories. Chapel Hill: University of North Carolina Press, 2000.

CUNHA, Euclides da. Rebellion in the Backlands. Chicago: University of Chicago Press, 1944.

DEAN, Warren. "Latifundia and Land Policy in Nineteenth-Century Brazil," Hispanic American Historical Review 51, no. 4, 1971.

,Warren. With Broadax and Firebrand: The Destruction of the Brazilian Atlantic Forest. Berkeley: University of California Press, 1995.

DUARTE, Regina Horta. "Por um pensamento ambiental histórico: O caso do Brasil," LusoBrazilian Review 41, no. 2, 2005.

EISENBERG, Peter. The Sugar Industry in Pernambuco: Modernization Without Change, 1840-1910. Berkeley: University of California Press, 1974.

FRENCH, John D. "A História Latino-Americana do Trabalho Hoje: Uma Reflexão AutoCrítica.” Revista de Historia. UNISINOS, Rio Grande do Sul, no. 6, 2002.

FREYRE, Gilberto. Casa-Grande e Senzala: Formação da Família Brasileira sob o Regime de Economia Patriarcal, 14th Ed. Recife: Imprensa Oficial, 1966.

, Gilberto. "Joaquim Nabuco e as Reformas Sociais," introdução a Joaquim Nabuco, O Abolicionismo, 4th Ed, Petrópolis: Editora Vozes, 1977.

, Gilberto. Nordeste: Aspectos da Influência da Cana sobre a Vida e a Paisagem do Nordeste do Brasil, 6a Ed. Rio de Janeiro: Editora Record, 1989 [1937].

Gilberto Tempo Morto e Outros Tempos: Trechos de um Diário de Adolescência e Primeira Mocidade, 1915-1930. Rio de Janeiro: José Olympio, 1975.

Gilberto The Mansions and the Shanties: The Making of Modern Brazil, trans. Harriet de Onís, intro. Frank Tannenbaum. New York: Alfred A. Knopf, 1963. (a)

, Gilberto, The Masters and the Slaves: A Study in the Development of Brazilian Civilization, 2d English ed, Samuel Putnam, trans. New York: Alfred A. Knopf, 1963. (b)

GALLOWAY, Joey H. "The Last Years of Slavery on the Sugar Plantations of Northeastern Brazil," The Hispanic American Historical Review 51, no. 4, 1971. 
GREENFIELD, Gerald. The Realities of Images. Imperial Brazil and the Great Drought. Philadelphia: American Philosophical Society, 2001.

GREIDER, Thomas, GARKOVICH, Lorraine. "Landscapes: The Social Construction of Nature and the Environment," Rural Sociology 59, no. 1, 1994.

HUNTINGTON, Ellsworth. Civilization and Climate. New Haven: Yale University Press, 1915.

LEFF, Nathaniel H. "Economic Development in Brazil, 1822-1913," in Stephen Haber, ed., How Latin America Fell Behind: Essays on the Economic Histories of Brazil and Mexico, 1800-1914. Stanford: Stanford University Press, 1997.

LINS DO REGO, José. Banguê, publicado com Plantation Boy. New York: Alfred A. Knopf, 1966 a.

, José. Doidinho, publicado com Plantation Boy (1966)b.

, José. Fogo Morto 57ª edição. Rio de Janeiro: José Olympio Editora, 2002.

, José. Menino de Engenho (Rio de Janeiro: Editora Nova Fronteira, tradução de: José Lins do Rego, Plantation Boy, 1986).

$1957[1956]$.

, José. Meus Verdes Anos (Memórias), 2 ed. Rio de Janeiro: José Olympio, , José. “Notas sobre Gilberto Freyre," in Freyre, Gilberto. Região e Tradição. Rio de Janeiro: Editora José Olympio, 1941.

, José. "Prefácio," in Bello, Memórias de um Senhor de Engenho, prefs. Gilberto Freyre, José Lins do Rego, 3 ed. Recife: FUNDARPE, 1985 [1935].

, José. Pureza, trad. Lucie Marion. New York: Hutchinson International

Authors, 1948.

, José. Usina, 2a Ed. Rio de Janeiro: José Olympio, 1940.

MELLO, Mário Lacerda de. "Problemas Agrícolas e Industriais do Açúcar em Pernambuco," Brasil Açucareiro 28, no. 6, 1946.

MENESES, Joedna Reis de. "A Indústria do Atraso ou O Atraso da Indústria? O Discurso da Industrialização no Nordeste 1950-1970,". Dissertação de Mestrado, Universidade Federal de Pernambuco, 1999.

MILET, Henrique Augusto. A Lavoura da Cana de Açúcar. Recife: Editora Massangana, 1989 [1881].

MILLIET, Sérgio. “A Obra de José Lins do Rego," in José Lins do Rego, Fogo Morto, 6 a edição. Rio de Janeiro: José Olympio, 1965 [1943]. 
ROGERS, T. D.

MOTA, Carlos Guilherme. Ideologia da Cultura Brasileira, 1933-1974, 9a ed (São Paulo: Editora Ática, 1994).

MOURA, Denise A. Soares de. Saindo das Sombras: Homens Livres no Declínio do Escravismo. Campinas: FAPESP, 1998.

NABUCO, Carolina. The Life of Joaquim Nabuco, trans. Ronald Hilton. Stanford: Stanford University Press, 1950.

NABUCO, Joaquim. Abolitionism: The Brazilian Antislavery Struggle, Robert Conrad, trans., ed. (Urbana: University of Illinois Press, 1977, (a)

$1981[1900]$. , Joaquim. Minha Formação (Brasília: Editora Universidade de Brasília, , Joaquim. O Abolicionismo, 4th ed (Petrópolis: Editora Vozes, 1977, (b)

, Joaquim. "Orçamento da Agricultura," 22 de março de 1879. Incluído em Discursos Parlamentares (1879-1889), Obras Completas vol. 11. São Paulo: Instituto Progresso Editorial, 1949.

PÁDUA, José Augusto. 'Cultura esgotadora': agricultura e destruição ambiental nas ultimas décadas do Brasil Império,” Estudos de Sociedade e Agricultura 11, 1998.

RADDING, Cynthia. Landscapes of Power and Identity: Comparative Histories in the Sonoran Desert and the Forests of Amazonia from Colony to Republic. Durham: Duke University Press, 2005.

RAFFLES, Hugh. In Amazonia: A Natural History. Princeton: Princeton University Press, 2002.

RAIZ, Jovino da. "O trabalhador negro no tempo do banguê comparado com o trabalhador negro no tempo das usinas de açúcar,” in Estudos Afro-Brasileiros. Recife: Editora Massangana, 1988.

ROGERS, Thomas D. The Deepest Wounds: The Laboring Landscapes of Sugar in Northeast Brazil. Chapel Hill: The University of North Carolina Press, 2010.

SCHAMA, Simon. Landscape and Memory. New York: Vintage, 1995.

SEMPLE, Ellen Churchill. Influences of Geographic Environment on the Basis of Ratzel's System of Anthropo-Geography. New York: Russell and Russell, 1911.

SHORT, John Rennie. Imagined Country: Society, Culture and the Environment. New York: Routledge, 1991.

SKIDMORE, Thomas E. Black into White: Race and Nationality in Brazilian Thought. Durham: Duke University Press, 1993. 
$34(2002)$.

,Thomas E. "Raízes de Gilberto Freyre," Journal of Latin American Studies

Sociedade Auxiliadora da Agricultura de Pernambuco, Trabalhos do Congresso Agrícola do Recife. Recife: Fundação Estadual de Planejamento Agrícola de Pernambuco, 1978 [1879].

STEINBERG, Ted "Down to Earth: Nature, Agency, and Power in History," American Historical Review 107, no. 3, 2002.

TAYLOR, Thomas Griffith. Environment and Race: A Study of the Evolution, Migration, Settlement and Status of the Races of Man. London: Oxford University Press, 1927.

TOLLENARE, L. F. Notas Dominicais, tomadas durante uma viagem em Portugal e no Brasil em 1816, 1817 e 1818. Bahia: Livraria Progresso Editora, 1956.

TRIGO, Luciano. Engenho e Memória: O Nordeste do Açúcar na Ficção de José Lins do Rego. Rio de Janeiro: Topbooks, 2002.

TUAN, Yi-Fu. "Place: An Experiential Perspective," The Geographical Review 65, no. 2, 1975, (p. 151-165).

WORSTER, Donald. "Transformations of the Earth: Toward an Agroecological Perspective in History," The Journal of American History 76, no. 4, 1990, (p. 1099-1100). 